\title{
ВЛИЯНИЕ ТРАППОВОГО МАГМАТИЗМА НА ГЕОХИМИЮ РАССОЛОВ НЕФТЕГАЗОНОСНЫХ ОТЛОЖЕНИЙ ЗАПАДНЫХ РАЙОНОВ КУРЕЙСКОЙ СИНЕКЛИЗЫ (СИБИРСКАЯ ПЛАТФОРМА)
}

\author{
Новиков Д. А., Гордеева А. О., Черных А. В., Дульцев Ф. Ф., Житова Л. М.
}

\begin{abstract}
Аннотация
Приводятся результаты по изучению влияния траппового магматизма на геохимию рассолов и геотермический режим недр западных районов Курейской синеклизы. Сибирская трапповая провинция, объединяющая все секущие и послойные интрузивные образования толеит-базитовой магмы, а также излившиеся на поверхность базальтовые лавы, является самой крупной континентальной базальтовой провинцией фанерозойского возраста на планете. Рассолы, залежи углеводородов и органическое вещество осадочного чехла, подвергались значительному тепловому воздействию в результате проявления траппового магматизма на рубеже перми и триаса. Максимальные палеотемпературы на момент внедрения траппов для основных продуктивных горизонтов силура (дьявольский), ордовика (байкитский) и кембрия (дельтулино-таначинский, абакунский и моктаконский) достигали 650 оС. В отложениях палеозоя и протерозоя исследуемой территории развиты рассолы с величиной общей минерализации от 50 до 470 г/дм3. По химическому составу они относятся к хлоридным натриевым, натриево-кальциевым, кальциевонатриевым, кальциево-магниевым и кальциевым (по С.А. Щукареву), при доминировании смешанных хлоридных кальциево-натриевых и натриево-кальциевых типов. По степени метаморфизации изученные рассолы можно разделить на три группы: слабой (S1), средней (S2) и сильной (S3). K первой относятся преимущественно хлоридные натриевые рассолы с величиной общей минерализации от 50 до 370 г/дм3 (rNa/rCl = 0,60-0,95; $\mathrm{S} \leq 100)$. Вторая - наиболее многочисленная группа объединяет рассолы хлоридного натриево-кальциевого, кальциевонатриевого, кальциевого и кальциево-магниевого состава с минерализацией от 150 до 470 г/дм3 $(\mathrm{rNa} / \mathrm{rCl}=0,10-0,87 ; 300 \geq \mathrm{S} \geq 100)$. И к третьей группе относятся рассолы хлоридного кальциевонатриевого и кальциевого состава с минерализацией от 223 до 381 г/дм3 (rNa/rCl = 0,12-0,45; S $\geq$ 300). Впервые установлены изменения в гидрогеохимическом поле (макро-, микрокомпонентный и газовый состав) по мере удаления от контактов, внедрившихся силлов и даек долеритов. Углеводородные и компоненты имеющие органическую природу в свободной и водорастворенной форме (CH4, C2H6, C3H8, iC4H10, nC4H10, iC5H12, nC5H12, C6H14, I, B, NH4) наиболее активно подвергались процессам деструкции. Так, если в зоне влияния интрузии до 100 м в составе водорастворенных газов доминирует углекислый газ с содержанием более 90 об.\%, при содержании метана до 5 об.\%, то на расстоянии уже в 250 м концентрации СО2 падают до 30 об.\%, а СН4 растут до 60-70 об.\%. Интрузивный трапповый магматизм помимо негативного влияния на сохранность углеводородов в контактовой зоне (до 400 м) способствовал процессу вызревания углеводородов в удаленных от контакта горизонтах. В результате реакционного взаимодействия внедряющихся траппов с рассолами осадочного чехла значительно преобразовался исходный состав последних в направлении их насыщения железом, алюминием и кремнеземом, что может служить подтверждением возможности солевой экстракции металлов в рудоносный флюид из магматических расплавов.
\end{abstract}

\section{Ключевые слова:}

Гидрогеология, геохимия рассолов, степень метаморфизации, трапповый магматизм, интрузия, палеотемпературы, нефтегазоносность, Курейская синеклиза, Сибирская платформа, Арктика 
УДК 556.3

\title{
ВЛИЯНИЕ ТРАППОВОГО МАГМАТИЗМА НА ГЕОХИМИЮ РАССОЛОВ НЕФТЕГАЗОНОСНЫХ ОТЛОЖЕНИЙ ЗАПАДНЫХ РАЙОНОВ КУРЕЙСКОЙ СИНЕКЛИЗЫ (СИБИРСКАЯ ПЛАТФОРМА)
}

\author{
(C) 2019 г. Д.А. Новиков ${ }^{1,2 *}$, А.О. Гордеева ${ }^{1}$, А.В Черных ${ }^{1}$, Ф.Ф. Дульцев ${ }^{1}$, \\ Житова Л.М. ${ }^{3}$ \\ ${ }^{1}$ Институт нефтегазовой геологии и геофизики им. А.А. Трофимука СО РАН \\ Россия, 630090 Новосибирск, проспект Академика Коптюга, 3 \\ ${ }^{2}$ Новосибирский национальный исследовательский государственный университет \\ Россия, 630090 Новосибирск, ул. Пирогова, 1 \\ ${ }^{3}$ Институт геологии и минералогии им. В.С. Соболева СО РАН \\ Россия, 630090 Новосибирск, проспект Академика Коптюга, 3 \\ *E-mail: NovikovDA@ipgg.sbras.ru
}

\begin{abstract}
Приводятся результаты по изучению влияния траппового магматизма на геохимию рассолов и геотермический режим недр западных районов Курейской синеклизы. Сибирская трапповая провинция, объединяющая все секущие и послойные интрузивные образования толеит-базитовой магмы, а также излившиеся на поверхность базальтовые лавы, является самой крупной континентальной базальтовой провинцией фанерозойского возраста на планете. Рассолы, залежи углеводородов и органическое вещество осадочного чехла, подвергались значительному тепловому воздействию в результате проявления траппового магматизма на рубеже перми и триаса. Максимальные палеотемпературы на момент внедрения траппов для основных продуктивных горизонтов силура (дьявольский), ордовика (байкитский) и кембрия (дельтулино-таначинский, абакунский и моктаконский) достигали $650{ }^{\circ} \mathrm{C}$. В отложениях палеозоя и протерозоя исследуемой территории развиты рассолы с величиной общей минерализации от 50 до 470 г/дм³ . По химическому составу они относятся к хлоридным натриевым, натриево-кальциевым, кальциево-натриевым, кальциево-магниевым и кальциевым (по С.А. Щукареву), при доминировании смешанных хлоридных кальциево-натриевых и натриево-кальциевых типов. По степени метаморфизации изученные рассолы можно разделить на три группы: слабой $\left(\mathrm{S}_{1}\right)$, средней $\left(\mathrm{S}_{2}\right)$ и сильной $\left(\mathrm{S}_{3}\right)$. K первой относятся преимущественно хлоридные натриевые рассолы с величиной общей минерализации от 50 до 370 г/дм ${ }^{3}(\mathrm{rNa} / \mathrm{rCl}=0,60-0,95 ; \mathrm{S} \leq 100)$. Вторая - наиболее многочисленная группа объединяет рассолы хлоридного натриево-кальциевого, кальциево-натриевого, кальциевого и кальциево-магниевого состава с минерализацией от 150 до 470 г/дм ${ }^{3}(\mathrm{rNa} / \mathrm{rCl}=0,10-0,87 ; 300 \geq \mathrm{S} \geq 100)$. И к третьей группе относятся рассолы хлоридного кальциево-натриевого и кальциевого состава с минерализацией от 223 до 381 г/дм ${ }^{3}(\mathrm{rNa} / \mathrm{rCl}=0,12-0,45 ; \mathrm{S} \geq 300)$. Впервые установлены изменения в гидрогеохимическом поле (макро-, микрокомпонентный и газовый состав) по мере удаления от контактов, внедрившихся силлов и даек долеритов. Углеводородные и компоненты имеющие органическую природу в свободной и водорастворенной форме $\left(\mathrm{CH}_{4}, \mathrm{C}_{2} \mathrm{H}_{6}, \mathrm{C}_{3} \mathrm{H}_{8}, \mathrm{iC}_{4} \mathrm{H}_{10}, \mathrm{nC}_{4} \mathrm{H}_{10}, \mathrm{iC}_{5} \mathrm{H}_{12}\right.$, $\mathrm{nC}_{5} \mathrm{H}_{12}, \mathrm{C}_{6} \mathrm{H}_{14}, \mathrm{I}, \mathrm{B}, \mathrm{NH}_{4}$ ) наиболее активно подвергались процессам деструкции. Так, если в зоне влияния интрузии до 100 м в составе водорастворенных газов доминирует углекислый газ с содержанием более 90 об.\%, при содержании метана до 5 об.\%, то на расстоянии уже в 250 м концентрации СО 2 падают до 30 об.\%, а $\mathrm{CH}_{4}$ растут до 60-70 об.\%. Интрузивный трапповый магматизм помимо негативного влияния на сохранность углеводородов в контактовой зоне (до 400 м) способствовал процессу вызревания углеводородов в удаленных от контакта горизонтах. В результате реакционного взаимодействия внедряющихся траппов с рассолами осадочного чехла значительно преобразовался исходный состав последних в направлении их насыщения железом, алюминием и кремнеземом, что может служить подтверждением возможности солевой экстракции металлов в рудоносный флюид из магматических расплавов.
\end{abstract}

Гидрогеология, геохимия рассолов, степень метаморфизации, трапповый магматизм, интрузия, палеотемпературы, нефтегазоносность, Курейская синеклиза, Сибирская платформа, Арктика. 
Залежи углеводородов, органическое вещество осадочных пород и рассолы чехла Сибирской платформы подверглись значительному тепловому воздействию в результате проявления траппового магматизма на рубеже перми и триаса. Влияние этого процесса на вещественный состав рассолов практически не изучалось. В настоящей статье впервые показаны результаты комплексного анализа и интерпретации всех имеющихся гидрогеологических материалов, полученных при поисково-разведочном и глубоком бурении в западных районах Курейской синеклизы (Южно-Тунгусская нефтегазоносная область Лено-Тунгусской нефтегазоносной провинции) (рис. 1), где установлена уникальная насыщенность геологического разреза интрузивными телами (до 50\% мощности). Это позволило реконструировать геотермический режим недр, изучить влияние траппового магматизма на состояние пластовых рассолов и нефтегазоносность. Территория исследований характеризуется присутствием крепких рассолов, развитием мощных толщ соленосных отложений, криогенной толщи, траппов, наличием древнейших рифей-раннекембрийских нефтегазоносных комплексов. Все это обуславливает ряд проблем, связанных с оценкой нефтегазоносности, в частности с геотермическим режимом недр. Одна из ключевых проблем - сохранность углеводородов в залежах [Конторович и др., 1987; Конторович и др., 1997а; Конторович, Хоменко, 2001; Новиков, Кох, 2014].

Вопросы изучения гидрогеологических условий и геотермического режима недр Сибирской платформы обсуждаются в работах А.С. Анциферова, С.В. Алексеева, В.Т. Балобаева, Е.А. Баскова, Г.В. Богомолова, М.Б. Букаты, А.П. Булмасова, М.Г. Валяшко, В.И. Вожова, В.А. Голубева, А.А. Дзюбы, А.Д. Дучкова, И.К. Зайцева, Ю.А. Зорина, В.Н. Девяткина, Е.В. Ильиной, Ю.И. Кустова, И.С. Ломоносова, Б.Н. Любомирова, С.В. Лысак, Ф.А. Макаренко, В.В. Павленко, Е.В. Пиннекера, Л.С. Соколовой, А.И. Сурнина, В.Г. Ткачук, Н.И. Толстихина, Н.Я. Тычино, С.Л. Шварцева и многих других. 
[Анциферов и др., 1971; Богомолов и др., 1971; Басков, 1977; Вожов, 1987; Дучков и др., 1987; Анциферов, 1989; Шварцев, 2000; Вожов, 2006; Букаты, 2009; Новиков, Кох, 2014; Алексеев и др., 2017; Novikov, 2017а; Алексеева, Алексеев, 2018; Novikov, 2018; Novikov et al, 2018; Сидкина, 2018].

Влияние траппового магматизма на вмещающие осадочные породы, а также его влияния на процессы преобразования органического вещества, газо- и нефтеобразования, формирования и сохранения залежей углеводородов (УВ) рассматривались в работах А.С. Борисенко, А.О. Гордеевой, Л.В. Жидковой, А.Э. Конторовича, Е.Н. Кузнецовой, А.А. Лапковского, М.П. Мазурова, Н.В. Мельникова, А.В. Павлова, О.П. Полянского, В.В. Ревердатто, В.В. Рябова, В.С. Старосельцева, А.Т. Титова, Г.А. Третьякова, А.В. Хоменко, В.Н. Шарапова и других исследователей [Конторович и др., 1987; Конторович и др., 1995; Конторович и др., 1996а; Конторович и др., 1996б; Конторович и др., 1997б; Хоменко, 1997; Мазуров, Титов, 1999; Конторович, Хоменко, 2001; Полянский, Ревердатто, 2002; Polansky et al., 2003; Полянский, Ревердатто, 2006; Шарапов и др., 2009; Svensen et al., 2009; Ryabov, Lapkovsky, 2010; Iacono-Marziano et al., 2012; Каменецкий и др., 2013; Новиков, Кох, 2014; Мазуров и др., 2018; Novikov et al., 2019 и др.].

\section{ФАКТИЧЕСКИЙ МАТЕРИАЛ}

K настоящему времени накоплен обширный фактический материал по геологической изученности нефтегазоносности Сибирской платформы. Особый интерес представляет ее западная часть, где как отмечалось ранее в пределах Курейской синеклизы выявлена уникальная насыщенность геологического разреза интрузиями траппов. Здесь в 60-90 годы прошлого века силами Туруханской, Туринской, Ванаварской и Нижнеенисейской нефтегазогеологоразведочных экспедиций пробурены 187 структурно-колонковых скважин до глубин 1200-1400 м и 67 глубоких скважин до 
глубин 2500-4200 м, из которых нижние горизонты кембрия вскрыли 31 скважина и карбонатный комплекс венда - 16 скважин [Кузнецова и др., 2017].

В основу настоящего исследования положены структурные карты по основным отражающим горизонтам (кровли устьмундуйской свиты $\left(\epsilon_{2-3}\right)$, дельтулинской свиты $\left(\epsilon_{1} \mathrm{dl}\right)$, булайской свиты $\left(\epsilon_{1} \mathrm{bl}\right)$, бурусской свиты $\left(\epsilon_{1} \mathrm{br}\right)$, усольской свиты $\left(\epsilon_{1} \mathrm{us}\right)$, тэтэрской свиты $\left(\mathrm{V}-\mathrm{G}_{1}\right)$ и кристаллического фундамента), составленным в ИНГГ СО РАН под руководством академика А.Э. Конторовича, испытания по 94 объектам 18 поисковых площадей, 55 термометрий по глубоким скважинам. Электронная база данных представлена записями по 126 пробам рассолов, 42 пробам водорастворенных газов и 24 пробам свободных газов залежей углеводородов. Наибольшей изученностью отличается соленосная формация, где охарактеризованы ангарско-литвинцевский, булайский, бельский и усольский водоносные горизонты. Следующей по степени изученности можно считать надсолевую формацию. Накопление фактического материала проходило в течение длительного времени. Лабораторное изучение ионносолевого, микроэлементного и газового состава методами титриметрии, ионной хроматографии, масс-спектрометрии с индуктивно связанной плазмой (ИСП) проводилось в лабораториях ВНИГРИ, ВНИИЯГГ, ВостСибНИИГГиМС, КГЭ ЕНГГ, ИЗК СО РАН, Норильской экспедиции, Севморгео, СНИИГГиМС, ТО СНИИГГиМС, ТПУ, ТНГРЭ, ТурухНГРЭ и др.

На основе прямых измерений пластовых температур в скважинах, средних геотермических градиентов и регрессионных зависимостей путем экстраполяции в программе GridMaster и Surfer был составлен комплект карт распределения пластовых температур по кровлям основных отражающих горизонтов. Это позволило построить геотермическую модель осадочного чехла, позволяющую прогнозировать изменение геотермических параметров по площади и разрезу, что особенно актуально для районов 
проведения и проектирования геологоразведочных работ с низкой плотностью бурения и отсутствием качественных материалов по вскрытию и опробованию продуктивных горизонтов.

$\begin{array}{rrrrr}\text { Максимальные } & \text { температуры } & \text { прогрева для изученных } & \text { объектов с } \\ \text { гидрогеохимическим } & \text { опробованием } & \text { вычислялись по методике предложенной }\end{array}$
коллективом под руководством А.Э. Конторовича [Конторович и др., 2001; Конторович, Хоменко, 2001]. Изначально был выполнен анализ всех близкорасположенных интрузий траппов, рассчитаны расстояния изученных интервалов до траппов, находящихся выше и ниже по разрезу, что позволило выделить две группы с мощностью траппов менее и более 100 м. Далее было вычислено отношение расстояние до траппа к его мощности и вычислена температура прогрева пород. Для определения какая из интрузий оказала наибольшее влияние на исследуемый интервал опирались на полученное значение отношения. Чем меньше его величина, тем выше температура и больше влияние тепла интрузий траппов на исследуемый интервал. Причем согласно полученным зависимостям при остывании внедрившихся траппов в осадочные породы, температура снижается нелинейно, при удалении от траппа на расстояние больше 6 толщин интрузива температура снижается незначительно - 8-10 $\mathrm{C}$ на каждую мощность. Там, где трапп был удален на расстояние больше 15-20 его мощностей, температуры снижались согласно среднему термическому градиенту равному $1.5-2.0^{\circ} \mathrm{C}$ на каждые $100 \mathrm{M}$.

Для сравнения уровня метаморфизации нами был применен интегрированный показатель метаморфизации рассолов (S) по С.Л. Шварцеву [Шварцев, 2000], который используется в подобных исследованиях по регионам с наличием в гидрогеологическом разрезе рассолов и рассчитывается по формуле: 


$$
S=\frac{\frac{C a}{C l}(\text { пробы })}{\frac{C a}{C l}(\text { морской рапы })}+\frac{\frac{S r}{C l}(\text { пробы })}{\frac{S r}{C l}(\text { морской рапы })}+\frac{\frac{B r}{C l}(\text { пробы })}{\frac{B r}{C l}(\text { морской рапы })}
$$

Степень метаморфизации подземных вод и рассолов во многом определяется по отношениям $\mathrm{Ca} / \mathrm{Cl}, \mathrm{Br} / \mathrm{Cl} \cdot 10^{-3}, \mathrm{Sr} / \mathrm{Cl} \cdot 10^{-3}$, поскольку суть метаморфизации наиболее ярко проявляется в увеличении после их захоронения за счет взаимодействия с вмещающими горными породами содержаний $\mathrm{Ca}$, $\mathrm{Sr}$ и $\mathrm{Br}$. При описании геохимических особенностей рассолов были также использованы коэффициенты $\mathrm{rNa} / \mathrm{rCl}$ и $\mathrm{Cl} / \mathrm{Br}$.

\section{РЕЗУЛЬТАТЫ ИССЛЕДОВАНИЙ И ОБСУЖДЕНИЕ}

\section{Особенности геологического строения}

По данным тектонического районирования венд-нижнепалеозойского структурного яруса Сибирской платформы территория исследования приурочена к надпорядковой отрицательной структуре - Курейской синеклизе, которая осложнена двумя положительными структурами 1-го порядка - Бахтинско-Кондроминским и Нижнечункунским выступами [Конторович и др., 2009]. Кристаллический фундамент в районе Курейской синеклизы является сложнодислоцированным тектоническим сооружением, имеющим блоковое строение, что обусловлено различной плотностью пород в разных участках [Медведев и др., 2003; Васильев и др., 2008]. Возраст фундамента - ранний-средний протерозой, глубины изменяются от 3,5 в центральной части Бахтинско-Кондроминского выступа до 7 км к западному борту Курейской синеклизы в сторону Приенисейского мегапрогиба и Имбакской котловины.

Осадочный чехол представлен отложениями верхнепротерозойского, палеозойского и нижнемезозойского (триас) возраста. Рифейские карбонатные и вендские терригенные отложения распространены преимущественно в западной и восточной частях исследуемой территории. Выше залегают карбонатные, сульфатно- 
галогенно-карбонатные комплексы венда и нижнего-среднего кембрия, которые перекрыты ордовикскими, силурийскими, девонскими, пермокарбоновыми и нижнетриасовыми отложениями (рис. 2). Общая толщина осадочного чехла в наиболее приподнятой центральной части достигает 3,7-4,0 км и увеличивается до 8-10 км к западному борту Курейской синеклизы [Кузнецова и др., 2017]. Общая мощность пластов кембрийских солей на западе Сибирской платформы местами достигает 550600 м [Novikov, 2017б]. Детальная информация о стратиграфии осадочного чехла Южно-Тунгусской НГО содержится в серии работ монографии «Стратиграфия нефтегазоносных бассейнов Сибири» [Тесаков и др., 2000; Девятов и др., 2002; Мельников и др., 2005; Каныгин и др., 2008; Сухов и др., 2016 и др.].

Впервые широкое развитие интрузивных траппов на западе Сибирской платформы в междуречье Нижней и Подкаменной Тунгусок описано В.С. Соболевым [Соболев, 1936], который также отметил развитие метасоматических ореолов и рудной минерализации в контактах трапповых тел. В настоящее время установлено, что суммарная толщина трапповых тел достигает 30-50 \% от всего объема осадочных пород осадочного чехла Южно-Тунгусской НГО. Распределение интрузий траппов в разрезе осадочного чехла неравномерно. Максимальное количество интрузий расположено в верхнепалеозойском комплексе, где объем интрузий достигает 40 \%, далее вниз по разрезу объем интрузий уменьшается, исчезая в отложениях венда (рис. 3). На исследуемой территории только в одной скв. Устькочумдекская 202 встречена интрузия, предположительно секущая [Хоменко, 1997].

Детальное изучение траппов в пределах Курейской синеклизы показало, что разнообразные по морфологии, размерам и внутреннему строению интрузивные тела имеют близкий возраст, обладают характерным петрохимическим и редкоземельным составом и образуют сложную «каркасную» тектономагматическую суперструктуру - 
Онекский интрузивный комплекс [Прусская, 1992; Прусская, Васильев, 2004; Васильев и др., 2008]. На разных уровнях разреза чехла трапповые тела комплекса имеют разное строение. По данным Ю.Р. Васильева с соавторами [Васильев и др., 2008] вблизи поверхности в породах среднего и верхнего палеозоя $\left(\mathrm{S}_{2}-\mathrm{T}_{1}\right)$ до глубины 1,5 км выявлена крупная интрузивная камера, имеющая в плане размеры $100 \times 100$ км. В пределах этого мощного траппового тела установлены крупные блоки ксенолитов осадочных пород, часто перевернутые, поднятые или опущенные относительно первичного залегания. Морфология тела осложнена послойными апофизами мощностью 100-300 м, прослеженными на расстояние до 70 км, вокруг тела зафиксированы многочисленные дайки. По керну глубоких скважин, вскрывших породы нижнего кембрия, установлено [Васильев и др., 2008], что количество пластовых интрузивных тел в разрезе чехла может достигать 15 , а их суммарная мощность 3 км, выявлены переходы пластовых тел с одних стратиграфических уровней на другие, выклинивание и разветвление на несколько тел небольшой мощности. Подобное расщепление послойных трапповых тел в соленосных отложениях ангарской свиты $\left(€_{1}\right.$ an) описано в Ангаро-Илимском районе, где трапповые инъекции занимают положение замещенных пластов каменной соли [Мазуров, Титов, 1999; Житова, 2000].

Мощные пластовые трапповые тела в пределах Курейской синеклизы имеют явно выраженное дифференцированное строение, которое проявлено в разном соотношении главных породообразующих минералов (оливина, пироксена и плагиоклаза). В прикровельных участках тел преобладают габбро-долериты лейкократовые, такситовые и трахитоидные, в центральных участках оливинсодержащие, троктолитовые и троктолит-пикритовые, нижние зоны тел сложены оливинсодержащими и безоливиновыми габбро-долеритами и микродолеритами в нижнем контакте [Васильев и др., 2007, Васильев и др., 2008]. По мнению этих 
исследователей, дифференцированное строение пластовых интрузивных тел отражает характер внутрикамерной дифференциации родоначального пикритоидного мантийного расплава, с незначительно проявленной коровой контаминацией в процессе внедрения и формирования интрузивного тела. По данным М.П. Мазурова с соавторами [Мазуров и др., 2014], магматическая рудная минерализация Онекского интрузивного комплекса представлена оксидными и сульфидными твердыми растворами, локализованными в интерстициях силикатов, с которыми они образуют графические мирмекитовые микроструктуры, характерные для интрузий норильского типа. Постмагматические оксиды и сульфиды образуют мелкую вкрапленность и прожилки в гидротермально измененных контактовых участках интрузивных тел.

Следует отметить, что внедрение пластовых трапповых интрузий в сульфатнокарбонатно-соленосные эвапоритовые отложения чехла приводит к значительным изменениям всех пород. Базитовый расплав на контакте с эвапоритами вскипает с формированием капель, в результате кристаллизации которых образуются глобули долеритов в кальцифирах [Мазуров, Титов, 1999; Житова, 2000]. В контактовых зонах долеритовых глобулей и интрузивных тел формируются эндо- и экзоконтактовые скарны с магнетитовым и сульфидным оруденением. При реакционном взаимодействии базитового расплава и карбонатно-эвапоритовых отложений происходит плавление каменных солей. Изучение солевых включений в форстеритах из магнезиальных скарнов в контакте долеритов с каменной солью ангарской свиты ( $\epsilon_{1}$ an) показало [Житова, 2000], что солевой расплав, содержащий тонкодисперсные фазы пирротина, магнетита и алюмошпинели, мог захватываться форстеритом при температурах 9501010 들 значительно выше температуры гомогенизации солевого расплава (740$\left.820^{\circ} \mathrm{C}\right)$ 
По данным изучения включений в галитах, который консервирует форстериты в магнезиальных скарнах [Гришина и др., 1987; Grishina et al., 1992], наиболее высокотемпературными (температура плавления $580-600{ }^{\circ} \mathrm{C}$ ) являются безводные включения в крупноблоковом галите из контактов с долеритами. Включения представлены $\mathrm{nMgCl} 2 \cdot \mathrm{mCaCl}_{2}$ в рудных зонах и $\mathrm{CaCl}_{2} \cdot \mathrm{KCl}$ в безрудных зонах скарнов. В галите и кальците из гнезд в галит-магнетитовых рудах обнаружены высокогигроскопичные многофазные солевые включения, содержащие в качестве одной из фаз $\mathrm{CaCl}_{2} \cdot 6 \mathrm{H}_{2} \mathrm{O}$. Во всех галитах ранних генераций встречены газовые включения высокой плотности, имеющие состав $\mathrm{CO}_{2}-\mathrm{H}_{2} \mathrm{~S}-\mathrm{N}_{2}-\mathrm{CH}_{4}$.

\section{Геотермический режим недр}

Неоднородное и сложнопостроенное геотермическое поле изучаемого региона в целом соответствует основным тектоническим элементам. Величины средних геотермических градиентов изменяются в небольших пределах от 1,5 до $2,0{ }^{\circ} \mathrm{C} / 100 \mathrm{M}$, а теплового потока от 30 до 50 мВт/м² [Дучков и др., 1987]. Минимальный прирост температур с глубиной установлен в галогенных и карбонатных породах, максимальный - в терригенных, что обусловлено изменениями теплофизических свойств пород.

Стоит отметить развитие в регионе исследования мощной криогенной толщи (более 400 м), которая формирует региональный экран, оказывающий большое влияние на геофлюидодинамическую систему и геотермический режим недр, а также представляет надежный флюидоупор для переформированных в неоген-четвертичное время залежей УВ [Вожов, 1987; Вожов, 2006; Букаты, 2009]. Нижне-средне палеозойские высококонцентрированные рассолы при внедрении в верхнепалеозойские и триасовые вулканогенно-терригенные породы смешиваются с минерализованными водами на глубинах $40-500$ м, что приводит к изменению их минерализации и 
химического состава. Например, аномалия на Нижнетунгусской площади, для которой характерен интенсивный тепловой поток, обусловливаемый разгрузкой хлоридных кальциевых рассолов [Дзюба, 1984]. В целом, на территории Тунгусского бассейна массовый характер разгрузки является причиной формирования большого количества сквозных таликов, связанных с разрывными нарушениями.

В южной части региона исследований, вне зоны активного влияния поверхностных факторов и криогенной толщи, установлена смена относительно повышенных геотермических градиентов в подсолевых отложениях на пониженные значения в породах соленосной формации и дальнейший рост градиентов в надсолевых комплексах, а кривая роста температур с глубиной в общем случае имеет «ступенчатый» вид. На основе структурных карт, составленных специалистами ИНГГ СО РАН и полученной регрессионной зависимости пластовых температур с глубиной: $\mathrm{T}=-(\mathrm{H}-292,32) / 85,58$, составлен комплект карт пластовых температур по основным стратиграфическим уровням (кровля устьмундуйской, дельтулинской, булайской, бурусской, усольской, тэтэрской и фундамента).

Детальный анализ фактических данных и результатов геотермических построений позволил выявить неоднородности геотермического разреза, связанные с его значительной литолого-фациальной изменчивостью. Наибольшей теплопроводностью обладают каменная соль, ангидрит, а песчаники, алевролиты, известняки и доломиты характеризуются средними значениями теплопроводности. Скачкообразные изменения кривых термометрии скважин установлены в кровлях и подошвах интрузивных тел. На базе имеющегося геотермического материала была создана схема распределения современных пластовых температур в кембрийском разрезе (рис. 4), которая позволяет решать прогнозные задачи на структурах слабо обеспеченных фактическими данными. Исследуемый регион имеет 
дифференцированно построенное геотермическое поле сложной конфигурации, являющееся следствием насыщенной событиями геологической истории.

Так, в кровле устьмундуйской свиты $\left(\epsilon_{2-3}\right)$ пластовые температуры изменяются в пределах от 0 до $20^{\circ} \mathrm{C}$, в интервале глубин от 100 до 2400 м. Максимальные температуры выявлены в Кочумдекской котловине и Курейской синеклизе. В пределах Бахтино-Кондроминского выступа пластовые температуры достигают $17^{\circ} \mathrm{C}$. B Фатъяниховском структурном заливе пластовые температуры не превышают $15{ }^{\circ} \mathrm{C}$. В кровле дельтулинской свиты $\left(\epsilon_{1} d l\right)$ пластовая температура варьирует от 12 до $34{ }^{\circ} \mathrm{C}$, при изменении глубины залегания от 700 до 3200 м. В Фатъяниховском заливе пластовая температура в среднем составляет в среднем $21^{\circ} \mathrm{C}$, варьируя от 18 до $24^{\circ} \mathrm{C}$. В пределах Бахтино-Кондроминского выступа и Курейской синеклизы температура достигает $30-31{ }^{\circ} \mathrm{C}$, в Кочумдекской котловине - до $29^{\circ} \mathrm{C}$. Тенденции распределения пластовых температур в кровле булайской свиты $\left(\epsilon_{1} b l\right)$ во многом схожи с закономерностями, выявленными в нижезалегающей, бурусской свите $\left(\epsilon_{1} b r\right)$ : от 26 до $52{ }^{\circ} \mathrm{C}$ и от 28 до $54{ }^{\circ} \mathrm{C}$ соответственно. Глубина залегания булайской и бурусской свиты изменяется в пределах 1700-4800 м и 2000-5000 м соответственно. Кровля усольской свиты ( $\left.\epsilon_{1} u s\right)$ залегает на глубинах от 2700 до 7100 м, а пластовые температуры изменяются в пределах $38-60{ }^{\circ} \mathrm{C}$ : Фатъяниховский структурный залив $-40-44{ }^{\circ} \mathrm{C}$, Кочумдекская впадина - $40-42^{\circ} \mathrm{C}$, Бахтино-Кондроминский выступ и Курейская синеклиза - $38-42^{\circ} \mathrm{C}$. В кровле тэтэрской свиты (V- $\left.\epsilon_{1}\right)$ пластовые температуры варьируют в пределах $42-82{ }^{\circ} \mathrm{C}$ и залегает на глубинах от 3000 до 8200 м. В Фатъяниховском структурном заливе - температуры достигают $51{ }^{\circ} \mathrm{C}$, Кочумдекской котловине и Курейской синеклизе $-46^{\circ} \mathrm{C}$, в Бахтино-Кондроминском выступе варьируют от 41 до $48{ }^{\circ} \mathrm{C}$. Кровля фундамента в районе исследования вскрыта 6 скважинами, расположенными на Таначинской, Моктаконской, Кочумдекской и 
Марской площадях. Карту пластовых температур по кровле кристаллического фундамента следует считать прогнозной, поскольку в этом интервале разреза практически не проводилось геотермических исследований. Кровля залегает на глубинах от 3700 до 11500 м. Пластовые температуры изменяются от 46 до 120 C.

Для оценки влияния интрузий на состав рассолов были рассчитаны максимальные палеотемпературы на момент внедрения траппов для основных продуктивных горизонтов силура (дьявольский), ордовика (байкитский) и кембрия (дельтулино-таначинский, абакунский и моктаконский) (рис. 5). В основу составления карт положена методика реконструкции максимальных температур на примере влияния Усольского (осинского) траппа на залежь Ярактинского нефтяного месторождения [Конторович и др., 2001]. Наиболее сильному прогреву подверглись силурийский и ордовикский горизонты, что обусловлено близостью к ним мощных пластовых интрузивов и незначительной мощностью продуктивных горизонтов (ПГ), наименьшему - нижнекембрийские.

Максимальные палеотемпературы для дьявольского ПГ изменяются от 260 до $650{ }^{\circ} \mathrm{C}$ (максимум отмечен на контакте силла с ПГ на Вакунайской площади) (см. рис. 5а). Практически вся территория исследований во время внедрения траппов находилась в зоне температур (более $400^{\circ} \mathrm{C}$ ). Лишь небольшие участки на Бахтинской, Таначинской, Сурингдаконской, Пойменной, Нижнетунгусской и Чисковской площадях расположены в диапазоне средних температур (400-300 $\left.{ }^{\circ} \mathrm{C}\right)$. Также на востоке и на западе территории дьявольская и ее стратиграфический аналог орловская свита незначительно подверглись влиянию траппов.

Максимальные температуры для байкитского ПГ изменяются от 220 до 630 ㄷ (максимумы отмечены на контакте силла с продуктивным горизонтом в скважинах Моктаконская 4, 7, где мощность горизонта составляет 51-52 м, а мощность интрузива - 
640-648 м) (см. рис. 5б). Область высоких температур (более $400{ }^{\circ} \mathrm{C}$ ) установлена на Устьдельтулинской, Бахтинской, Верхнеамнуннаканской, Вакунайской, Кочумдекской, Чисковской, Устькочумдекской и частично Нижнетунгусской площадях. Участки средних температур $\left(300-400^{\circ} \mathrm{C}\right)$ более обширны, по сравнению с территорией прогрева для дьявольского ПГ - это область Тутончанской, Учаминской, Марской, Малькитконской, Западно-Малькитконской, и частично Моктаконской, Нижнетунгусской и Таначинской площадей. Наименее всего байкитский горизонт был прогрет на Пойменной, Холминской и Сурингдаконской площадях - менее $250{ }^{\circ} \mathrm{C}$.

Дельтулино-таначинский горизонт во время внедрения траппов был прогрет меньше, чем вышележащие отложения ордовика и силура (см. рис. 5в). Это связано с количеством и мощностью пластовых тел и с более мощными отложениями дельтулино-таначинской толщи (до 800 м на Таначинской и Нижнетунгусской площадях). Участки прогрева до $300-400{ }^{\circ} \mathrm{C}$ занимают обширную территорию центральную, восточную и местами северную части района исследований. Область незначительного прогрева (ниже $300^{\circ} \mathrm{C}$ ) располагалась на востоке территории (Чисковская, Учаминская и Вакунайская площади), в центре (Сурингдаконская площадь) и частично на северо-западе (Пойменная и Нижнетунгусская, ВосточноНогинская площади).

Наименее затронуты прогревом интрузий толщи абакунского и моктаконского горизонтов (см. рис. 5г, д). Это обусловлено наличием одного Усольского силла, который ступенчато переходит с уровня на уровень в пределах ясенгской, моктаконской, марской и абакунской свит. Максимальные температуры в абакунском горизонте предполагаются в скважине Холминская 212 (выше $550{ }^{\circ} \mathrm{C}$ ). Поле средних температур (300-400 ㅇ) охватывает район скважин Малькитконская 211, Вакунайская 3, Моктаконская 6, 7, Нижнетунгусская 6 и Устьдельтулинская 214. Остальная 
территория была прогрета до температур ниже $300{ }^{\circ} \mathrm{C}$. Минимальному прогреву - ниже $200{ }^{\circ} \mathrm{C}$ горизонт был подвергнут на западе территории исследований и частично на Моктаконской площади (скважины 3 и 5). Моктаконский горизонт вскрыт наименьшим количеством глубоких скважин. Он наиболее сильно был прогрет на севере исследуемого района в скважине Малькитконская 211, что связано с расположением мощной интрузии непосредственно в горизонте. Достаточно сильно прогрет горизонт также в скважине Холминская 212 (выше $400{ }^{\circ} \mathrm{C}$ ), что связано с близкорасположенной мощной интрузией 140 м в абакунской свите. На Таначинской и Моктаконской площадях наблюдаются участки, где температуры прогрева моктаконского горизонта траппами были ниже $200{ }^{\circ} \mathrm{C}$.

Таким образом, наименьшему температурному влиянию подверглись рассолы абакунского и моктаконского ПГ, в средней степени - дельтулино-таначинского, и в большей степени - дьявольского и байкитского.

\section{Геохимия рассолов}

В отложениях палеозоя и протерозоя изучаемого региона установлены рассолы с величиной общей минерализации от 50,2 (надсолевая формация) до 469,6 г/дм³ (соленосная формация). По химическому составу рассолы относятся к хлоридным натриевым, натриево-кальциевым, кальциево-натриевым, кальциево-магниевым и кальциевым типам (по С.А. Щукареву), при доминировании смешанных хлоридных кальциево-натриевых и натриево-кальциевых типов (рис. 6). Отмечается тесная взаимосвязь минерализации и состава рассолов [Анциферов и др., 1971; Вожов, 1987; Шварцев, 2000; Букаты, 2009; Novikov, Trifonov, 2016; Novikov, 2017а; Алексеев и др., 2017; Novikov et al., 2018; Сидкина, 2018; Каширцев и др., 2019].

Доминируют кислые и слабокислые рассолы с величиной рН от 3,0 до 6,5. При минерализации ниже 300 г/дм³ практически все рассолы относятся к хлоридному 
натриевому типу, более минерализованные рассолы - к промежуточным натриевокальциевым и кальциево-натриевым, а при минерализации свыше 400-410 г/дм ${ }^{3}$ к кальциевым и кальциево-магниевым типам. Установлен прямой тип вертикальной гидрогеохимической зональности. Минерализация рассолов надсолевой формации в среднем составляет 310 г/дм³ , варьируя от 50,2 до 390,0 г/дм³. Минерализация рассолов соленосной формации достигает 469,6 г/дм³, при среднем значении 335 г/дм³ Наибольшей минерализацией обладают рассолы бельского и усольского водоносных горизонтов. Отмечается закономерный рост содержаний основных солеобразующих компонентов с увеличением величины общей минерализации рассолов (табл. 1). Среди катионов и анионов преобладают $\mathrm{Na}^{+}, \mathrm{Ca}^{2+}$ и $\mathrm{Cl}^{-}$, достигая 122,2, 109,5 и 287,0 г/дм ${ }^{3}$ соответственно. Остальные макрокомпоненты не превышают: $\mathrm{Mg}^{2+}-41,3 ; \mathrm{SO}_{4}{ }^{2-}-4,7$ и $\mathrm{HCO}_{3}{ }^{-}-3,7$ г/дм³ ${ }^{3}$ Содержания наиболее изученных элементов и соединений варьируют в широких пределах: $\mathrm{Br}-0,03-6,7$ г/дм ${ }^{3} \mathrm{NH}_{4}{ }^{+}-0,1-1,9$ г/дм ${ }^{3}, \mathrm{~B}-0,01-790,0$ мг/дм ${ }^{3}$ I 0,1-53,0 мг/дм $\mathrm{SiO}_{2}-2,0-86,0$ мг/дм³ и $\mathrm{F}-1,0-1,5$ мг/дм ${ }^{3}$. Спектр распределения средних содержаний некоторых элементов в кембрийских рассолах имеет следующий вид (мг/дм $\left.{ }^{3}\right): \mathrm{Br}_{3258}>\mathrm{Sr}_{1943}>\mathrm{B}_{237}>\mathrm{Li}_{175}>\mathrm{Fe}_{80}>\mathrm{Zn}_{32,2}>\mathrm{Rb}_{16,3}>\mathrm{Al}_{9,7}>\mathrm{I}_{9,0}>\mathrm{Mn}_{7,0}>\mathrm{Pb}_{5,3}>$ $\mathrm{Sn}_{3,5}>\mathrm{Ba}_{3,4}>\mathrm{F}_{1,1}>\mathrm{Ni}_{0,90}>\mathrm{Cs}_{0,65}>\mathrm{Cu}_{0,65}>\mathrm{Cd}_{0,40}>\mathrm{Ce}_{0,19}>\mathrm{Cr}_{0,15}>\mathrm{Hg}_{0,087}>\mathrm{Au}_{0,075}>\mathrm{Yb}_{0,042}>$ $\mathrm{Ag}_{0,018}>\mathrm{Co}_{0,011}>\mathrm{Hf}_{0,011}>\mathrm{Se}_{0,009}>\mathrm{Sb}_{0,005}>\mathrm{Sc}_{0,002}$.

Рассолы содержат водорастворенные газы (ВРГ) разнообразного состава ввиду значительного влияния процессов траппового магматизма на их геохимию. Установлены следующие химические типы ВРГ (по классификации Л.М. Зорькина): углеводородный класс с доминированием в составе $\mathrm{C}_{\mathrm{n}} \mathrm{H}_{\mathrm{m}} \geq 50$ об.\% (метановый, азотнометановый и углекисло-метановый типы); азотный класс с содержанием $\mathrm{N}_{2} \geq 50$ об.\% (азотный, метано-азотный и углекисло-азотный типы) и углекислый класс с содержанием $\mathrm{CO}_{2}+\mathrm{H}_{2} \mathrm{~S} \geq 50$ об.\% (углекислый и метано-углекислый типы) (рис. 7а). 
Газовые залежи изучаемого региона имеют схожий состав (рис. 7б). Для примера, ВРГ с содержанием в составе $\mathrm{CO}_{2}>90$ об.\% выявлены на Восточно- и Западно-Ногинской, Нижне-Тунгусской и Таначинской площадях. Установлена тенденция снижения его содержаний с глубиной и роста концентраций гелия до 0,40-0,52 об.\% в интервале 3250-3500 м. В поведении азота, водорода, метана и его гомологов четких зависимостей не выявлено, что связано с влиянием интрузий траппов и рассмотрено в следующем разделе.

Для оценки уровня метаморфизации рассолов (катагенетических изменений) нами был применен интегрированный показатель метаморфизации (S) по С.Л. Шварцеву [Шварцев, 2000], который используется в подобных исследованиях для регионов с наличием в гидрогеологическом разрезе рассолов. Установлены рассолы трех градаций по степени метаморфизации (рис. 8): слабой $\left(\mathrm{S}_{1}\right)$, средней $\left(\mathrm{S}_{2}\right)$ и сильной $\left(\mathrm{S}_{3}\right)$. K первой относятся преимущественно хлоридные натриевые рассолы с величиной общей минерализации от 50 до 370 г/дм³ $(\mathrm{rNa} / \mathrm{rCl}=0,60-0,95 ; \mathrm{S} \leq 100)$. Вторая наиболее многочисленная группа объединяет рассолы хлоридного натриевокальциевого, кальциево-натриевого, кальциевого и кальциево-магниевого состава с минерализацией от 150 до 470 г/дм ${ }^{3}(\mathrm{rNa} / \mathrm{rCl}=0,10-0,87 ; 300 \geq \mathrm{S} \geq 100)$. И к третьей группе относятся рассолы хлоридного кальциево-натриевого и кальциевого состава с минерализацией от 223 до 381 г/дм³ $(\mathrm{rNa} / \mathrm{rCl}=0,12-0,45 ; \mathrm{S} \geq 300)$.

Сравнительный анализ геохимических особенностей рассолов показал, что по $\mathrm{rNa} / \mathrm{rCl}, \mathrm{Ca} / \mathrm{Cl}, \mathrm{Cl} / \mathrm{Br}$ и другим отношениям все изученные воды обособляются в несколько геохимических групп (рис. 9). Первая (группа I) включает рассолы хлоридного натриевого состава и характеризуется величиной общей минерализации до 250 г/дм³ Интегрированный показатель метаморфизации рассолов S в них как правило не 
превышает 135. Во вторую (группу II) следует объединить рассолы переходных хлоридных натриево-кальциевых и кальциево-натриевых типов. Они характеризуются минерализацией от 166 до 405 г/дм ${ }^{3}, \mathrm{rNa} / \mathrm{rCl}$ коэффициент колеблется от 0,13 до 0,67; $\mathrm{Ca} / \mathrm{Cl}$ от 0,13 до 0,37, а показатель S составляет 96-376. K последней (группе III) с наибольшей степенью метаморфизации следует отнести крепкие рассолы хлоридного кальциевого и кальциево-магниевого состава с величиной общей минерализации, превышающей 350 г/дм³. Для них характерны низкие значения $\mathrm{rNa} / \mathrm{rCl}$ (до 0,24), $\mathrm{Cl} / \mathrm{Br}$ (до 50), повышенные значения $\mathrm{Ca} / \mathrm{Cl}$ (более 0,30 ) коэффициентов. Значения показателя S варьируют в основном около 300. Таким образом, уровень метаморфизации (катагенетических изменений) химического состава рассолов изучаемого региона повышается от наименее минерализованных $\mathrm{Cl}$ Na вод до крепких $\mathrm{Cl} \mathrm{Ca}$ и $\mathrm{Ca}-\mathrm{Mg}$ рассолов. Совместное рассмотрение $\mathrm{rNa} / \mathrm{rCl}, \mathrm{Ca} / \mathrm{Cl}, \mathrm{Br} / \mathrm{Cl} \cdot 10^{-3}$ и других отношений вместе с интегрированным показателем S подтверждает этот факт.

Влияние траппового магматизма на состав рассолов и нефтегазоносность осадочного чехла

Внедрение интрузий оказало огромное влияние на геохимические особенности рассолов. Максимальные температуры прогрева вмещающихся пород, внедрившихся интрузий траппов, достигали 200-600 을 концентраций в рассолах по мере приближения к контактам с интрузиями у натрия, калия, кальция, магния, ионов хлора, сульфат- и гидрокарбонат-иона. Например, у кальция интервал его содержаний составляет (г/дм³): на контакте - 35,2-70,3; на удалении 100 м - 28,8-70,2; на расстоянии 200 м - 36,1-74,0; на 300 м - 28,8-61,9; на 600 м - 38,7-69,1. Интервальные значения концентраций вне зависимости от расстояния до ближайшей интрузии у основных солеобразующих компонентов составляют $\left(г / \mathrm{дm}^{3}\right)$ : натрий - 18,1-78,4; калий - 2,8-26,4; кальций - 10,0-109,0; магний - 1,1-14,8; хлорид - 
103,5-286,6; гидрокарбонат-ион - 0,0-1,9 и сульфат-ион - 0,0-4,7. Также не установлено взаимосвязей между концентрациями основных макрокомпонентов с мощностями и температурами ближайшей интрузии и интрузии оказавшей максимальный прогрев.

Влияние траппов на содержание микроэлементов и соединений в рассолах проявилось не однозначно. Так, по мере приближения к контакту наблюдается рост концентраций железа, марганца, алюминия, иттербия, кремнезема и нитрит-иона (табл. 2). Их содержания составляют (в ближней зоне 0-100 м, на расстоянии от интрузии 350 и 700 м) (мг/дм³ $)$ (рис. 10): у железа - 840; 310; 25; у кремнезема - 86; 20; 5; у марганца - 60; 13; 5; у алюминия - 38; 1,5; 0,5; нитрит-иона - 10; 0,07; 0,02; у иттербия - 0,073; 0,035; 0,027. Таким образом, в результате реакционного взаимодействия внедряющихся траппов с рассолами осадочного чехла значительно преобразовался исходный состав последних в направлении их насыщения железом, алюминием, кремнеземом (рис. 10, аб) и другими компонентами, что может служить следствием солевой экстракции металлов в рудоносный флюид из магматических расплавов, но подтверждение этой гипотезы требует детальных литолого-минералогических и гидрогеохимических исследований.

Обратная тенденция характеризует поведение в рассолах брома, стронция, аммония, бора, лития, йода, рубидия, свинца, фтора, золота и селена. Их содержания составляют (в ближней зоне 0-100 м, на расстоянии от интрузии 350 и 700 м) (мг/дм³) (рис. 10): у брома - 421-4747; 2760-4595; 5770-6730; у стронция - 363-2080; 1854-3370; 1720-5231; у аммония - 27-250; 230-500; 600-1200; у бора - 0,2-0,5; 180-302; 423-540; у лития - 40-114; 148-163; 234-257; у йода - 0,8-17,6; 5,0-37,8; 31,7-53,0; у рубидия - 4,510,4; 9,9-21,0; 27,7-32,2; у свинца - 0,65-0,90; 0,90-2,30; 7,02; у фтора - 1,0; 1,2; 1,5; у золота - 0,06; 0,10; нет данных; у селена - 0,007; 0,01; нет данных. Максимальные концентрации лития (148-423 мг/дм³) отмечаются в интервале палеотемператур 200- 
$300{ }^{\circ} \mathrm{C}$, тогда как минимальные содержания - 40-169 мг/дм³ характеризуют диапазон 580-615 ${ }^{\circ} \mathrm{C}$. При тех же интервалах палеотемператур у рубидия наибольшие концентрации составляют 9,7-32,2 мг/дм ${ }^{3}$, а наименьшие $-4,5-10,4$ мг/дм ${ }^{3}$ соответственно. Схожие тенденции по накоплению микроэлементов в рассолах в

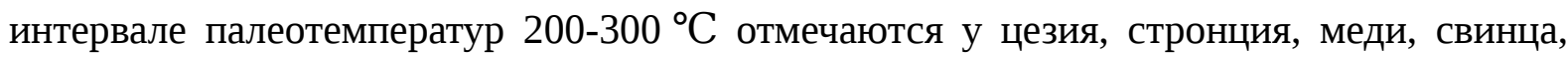
цинка, кадмия, кобальта, селена, ртути, олова, золота, сурьмы и церия. Однако изучение форм миграции и механизмов накопления элементов в рассолах при высоких температурах требует отдельного внимания поскольку является весьма трудоемкой задачей по моделированию взаимодействий в системе вода - горная порода.

Неравномерное, контрастное тепловое поле во время внедрения трапповых силлов обусловило существенное преобразование вмещающих пород и содержащегося в них органического вещества: резко активизируются процессы разложения УВ, происходит образование элементарного углерода и водорода, упрощение состава исходной смеси УВ. Наиболее ярко эти закономерности прослеживаются в изменении состава водорастворенных газов в зависимости от контакта с интрузией и температурой прогрева (табл. 3). Так, если в зоне влияния интрузии до 100 м в составе ВРГ доминирует углекислый газ с содержанием более 90 об. \%, при содержании метана до 5 об. \%, то на расстоянии 250 м концентрации $\mathrm{CO}_{2}$ падают до 30 об. \%, а $\mathrm{CH}_{4}$ растут до 60-70 об. \% (рис. 11a). Схожие тенденции наблюдаются для всего ряда гомологов от этана до гексана (рис. 11б). Их содержания составляют (в ближней зоне 0-100 м, на расстоянии от интрузии 350 и 600 м) (об.\%) (табл. 3, рис. 11б): у этана - 0,25; 3,5; нет данных; у пропана - 0,25; 2,2; нет данных; у изомерной формы бутана - 0,2; 0,8; нет данных; у нормальной формы бутана - 0,2; 0,7; 3,2; у изомерной формы пентана - 0,2; 0,6; 2,0; у нормальной формы пентана - 0,15; 0,5; 1,4 ; у гексана - 0,2; 0,6; 1,3. Как показали результаты расчетов палеотемператур, деструктивное влияние траппов на 
состав ВРГ прослеживается, начиная с $200{ }^{\circ} \mathrm{C}$ и сопровождается ростом содержаний углекислого газа до 80 об.\%. Влияние интрузивного тела на преобразование состава водорастворенных газов нивелируется на расстоянии около 400 м. В составе свободных газов залежей сохраняются те же тенденции, установленные ранее в работах А.Э. Конторовича с сотрудниками [Конторович и др., 1996в].

Траппы двояко повлияли на нефтегазоносность: с одной стороны - сильный прогрев осадочных пород (более $400{ }^{\circ} \mathrm{C}$ ) привел к почти полному уничтожению существующих УВ залежей, с другой стороны - нефтематеринские толщи попали в главную зону нефтегазообразования, что существенно увеличило стратиграфический диапазон нефтегазогенерации [Конторович и др., 2001] и привело к генерации углеводородов с формированием вторичных залежей [Конторович и др., 1996в; Конторович, Хоменко, 2001]. Также внедрившиеся траппы оказали существенное воздействие на коллекторские свойства ПГ - качество и выдержанность, активизировав процессы вторичных изменений в карбонатных породах. Высокие температуры, по мере удаленности траппа от ПГ, оказали значительное влияние на изменение фазового состава сформированных на момент внедрения пластовых интрузий залежей [Кузнецова и др., 2014]. Так при диапазоне температур 400-650 ํㅡ сохраняется менее 10 \% залежей с преобладанием в составе неорганических газов таких как $\mathrm{CO}_{2}, \mathrm{CO}$, COS. При температурах $400-300^{\circ} \mathrm{C}$ залежи также будут газовыми с преобладанием углекислого газа. Возможно наличие маломощной нефтяной оторочки тяжелых меркаптановых нефтей. При температурах $300-100{ }^{\circ} \mathrm{C}$ сохранится до 70 \% залежей. Залежи будут газонефтяные, преимущественно метановые с незначительным количеством конденсатных и неуглеводородных газов [Конторович и др., 2001].

Отличительной особенностью нефтей исследуемого района является высокая ароматичность низкокипящих фракций, что делает их похожими на нефть осинского 
горизонта Ярактинского месторождения [Конторович и др., 1996в], которая подверглась тепловому воздействию Усольского (осинского) силла. Так, для нефтей моктаконского горизонта характерны высокие концентрации серы (1,4-2,05\%), низкие содержания твердых парафинов (0,9-1,1\%), смол (0,95-6,55\%) и практически полное отсутствие асфальтенов. Конденсаты исследуемой территории также значительно отличаются от конденсатов других районов Сибирской платформы по содержанию аренов (56,15\% фракция, выкипающая до $125^{\circ} \mathrm{C}, 62,25-71 \%$ - фракция, выкипающая до $\left.200{ }^{\circ} \mathrm{C}\right)$ и сернистых соединений (1,64-6,5\%) [Конторович и др., 1996в], что объясняется процессами прогрева ПГ траппами.

\section{ЗАКЛЮЧЕНИЕ}

Резюмируя вышесказанное можно сделать следующие выводы:

1). В отложениях палеозоя и протерозоя исследуемой территории развиты рассолы хлоридного натриевого, натриево-кальциевого, кальциево-натриевого, кальциево-магниевого и кальциевого типов с величиной общей минерализации от 50,2 до 469,6 г/дм³. Доминируют кислые и слабокислые рассолы с величиной рН от 3,0 до 6,5. При минерализации ниже 300 г/дм³ практически все рассолы относятся к хлоридному натриевому типу, более минерализованные рассолы - к промежуточным натриево-кальциевым и кальциево-натриевым, а при минерализации свыше 400410 г/дм ${ }^{3}$ - к кальциевым и кальциево-магниевым типам. Водорастворенные и свободные газы залежей имеют схожий состав и относятся углеводородному, азотному и углекислому классам.

2). Установлены рассолы трех градаций по степени метаморфизации: слабой $\left(\mathrm{S}_{1}\right)$, средней $\left(\mathrm{S}_{2}\right)$ и сильной $\left(\mathrm{S}_{3}\right)$. $\mathrm{K}$ первой относятся преимущественно хлоридные натриевые рассолы с величиной общей минерализации от 50 до 370 г/дм ${ }^{3}(\mathrm{rNa} / \mathrm{rCl}=$ 0,60-0,95; S $\leq$ 100). Вторая - наиболее многочисленная группа объединяет рассолы 
хлоридного натриево-кальциевого, кальциево-натриевого, кальциевого и кальциевомагниевого состава с минерализацией от 150 до 470 г/дм³ $(\mathrm{rNa} / \mathrm{rCl}=0,10-0,87 ; 300 \geq \mathrm{S} \geq$ 100). И к третьей группе относятся рассолы хлоридного кальциево-натриевого и кальциевого состава с минерализацией от 223 до 381 г/дм³ $(\mathrm{rNa} / \mathrm{rCl}=0,12-0,45 ; \mathrm{S} \geq 300)$.

3). Осадочный чехол юго-западных районов Курейской синеклизы имеет дифференцированно построенное геотермическое поле сложной конфигурации, являющееся следствием насыщенной событиями геологической истории с интенсивным проявлением траппового магматизма, что обусловило существенное преобразование вмещающих пород и флюидов. Величина современных геотермических градиентов варьирует от 1,1 до $1,6^{\circ} \mathrm{C} / 100$ м. Расчёты палеотемператур на момент внедрения траппов для основных продуктивных горизонтов силура (дьявольский), ордовика (байкитский) и кембрия (дельтулино-таначинский, абакунский и моктаконский) показали, что их максимальные значения могли достигать $650{ }^{\circ} \mathrm{C}$. Установлено, что наименьшему температурному влиянию подверглись рассолы абакунского и моктаконского ПГ, в средней степени - дельтулино-таначинского, и в большей степени - дьявольского и байкитского.

4). Внедрение интрузий (палеотемпературы 200-650 ${ }^{\circ} \mathrm{C}$ ) оказало огромное влияние на геохимические особенности рассолов. Так, по мере приближения к контакту с интрузией наблюдается рост концентраций железа, марганца, алюминия, иттербия, кремнезема и нитрит-иона. Обратная тенденция характеризует поведение в рассолах брома, стронция, аммония, бора, лития, йода, рубидия, свинца, фтора, золота и селена. Не установлено существенных изменений концентраций в рассолах по мере приближения к контактам с интрузиями у натрия, калия, кальция, магния, ионов хлора, сульфат- и гидрокарбонат-иона. 
5). Влияние интрузий наиболее ярко выражено в составе водорастворенных газов. Так, если в зоне влияния интрузии до 100 м в составе ВРГ доминирует углекислый газ с содержанием более 90 об. \%, при содержании метана до 5 об. \%, то на расстоянии 250 м концентрации $\mathrm{CO}_{2}$ падают до 30 об. \%, а $\mathrm{CH}_{4}$ растут до 60-70 об. \%. Схожие тенденции установлены для всего ряда гомологов от этана до гексана. ВРГ с содержанием в составе $\mathrm{CO}_{2}>90$ об.\% выявлены на Восточно- и Западно-Ногинской, Нижне-Тунгусской и Таначинской площадях. Установлена тенденция снижения его содержаний с глубиной и роста концентраций гелия до 0,40-0,52 об.\% в интервале 32503500 м.

Исследования проводились при финансовой поддержке проектов ФНИ № 03312019-0025 «Геохимия, генезис и механизмы формирования состава подземных вод арктических районов осадочных бассейнов Сибири», № 0331-2019-0018 «Построение моделей геологического строения и оценка перспектив нефтегазоносности фанерозойских и неопротерозойских осадочных комплексов Лено-Тунгусской НГП для формирования программы геологоразведочных работ и лищензирования недр» и Российского фонда фундаментальных исследований в рамках научного проекта № 1805-70074 «Ресурсы Арктики».

\section{ЛИТЕРАТУРА}

Алексеева Л.П., Алексеев С.В. Геохимия подземных льдов, соленых вод и рассолов криоартезианских бассейнов северо-востока Сибирской платформы // Геология и геофизика. 2018, Т. 59, №2, с. 183-197.

Алексеев С.В., Алексеева Л.П., Шварцев С.Л., Трифонов Н.С., Сидкина Е.С. Особенности геохимической эволюции хлоридных кальциевых рассолов Оленекского криоартезианского бассейна в позднем кайнозое // Геохимия. 2017, № 5, с. 429-444. 
Анциферов А.С. Гидрогеология древнейших толщ Сибирской платформы. М.: Недра, 1989, 176 c.

Анциферов А.С., Артеменко А.С., Зехова О.В. Гидрогеология Иркутского нефтегазоносного бассейна. Иркутск: Вост-СибНИИГГиМС, 1971, 124 с.

Басков Е.А. Минеральные воды и палеогидрогеология Сибирской платформы. Труды ВСЕГЕИ. Новая серия. Том 254. М.: Недра, 1977, 148 с.

Богомолов Г.В., Силин-Бечкурин А.И., Духанина В.И., Панов В.В., Богомолов Ю.Г. Гидрогеология, гидрохимия, геотермия геологических структур. Минск: Наука и техника, 1971, 336 с.

Букаты М.Б. Гидрогеологическое строение западной части Сибирской платформы (в связи с поисками, разведкой и разработкой месторождений нефти и газа) // Геология и геофизика. 2009, Т. 50, № 11, с. 1201-1217.

Васильев Ю.Р., Прусская С.Н., Мазуров М.П. Новый тип крупнообъемных проявлений внутриплитного интрузивного траппового магматизма (Запад Сибирской платформы) //ДАН. 2007, Т. 413, №2, с. 213-217.

Васильев Ю.Р., Прусская С.Н., Мазуров М.П., Медведев А.Я., Альмухамедов А.И., Гора М.П. Онекский интрузивный комплекс - новый структурный тип крупнообъемных проявлений интрузивного траппового магматизма на Сибирской платформе // Геология и геофизика. 2008, Т. 49, №5, с. 395-409.

Вожов В.И. Гидрогеологические условия месторождений нефти и газа Сибирской платформы. М.: Недра, 1987, 204 с.

Вожов В.И. Подземные воды и гидроминеральное сырье Лено-Тунгусской нефтегазоносной провинции. Новосибирск: СНИИГГиМС, 2006, 209 с.

Девятов В.П., Казаков А.М., Константинов А.Г., Курушин Н.И., Могучева Н.К., Смирнов Л.В., Соболев Е.С., Фрадкина А.Ф., Ядренкин А.В. Стратиграфия 
нефтегазоносных бассейнов Сибири. Триасовая система. Новосибирск: «ГЕО», 2002, 322 c.

Дзюба А.А. Разгрузка рассолов Сибирской платформы. Новосибирск: Наука. Сибирское отделение, 1984, 156 с.

Дучков А.Д., Лысак С.В., Балобаев В.Т., Голубев В.А., Девяткин В.Н., Дорофеева Р.П., Зорин Ю.А., Казанцев С.А., Калинин А.Н., Курчиков А.Р., Лепина С.В., Силифонкин В.И., Соколова Л.С., Ставицкий Б.П., Ратников С.А., Цибульский В.P. Тепловое поле недр Сибири. Новосибирск: Наука, 1987, 198 с.

Житова Л.М. Минеральные типы и зональность железных руд Коршуновского месторождения (Сибирская платформа): автореферат дисс. .... канд. геол.-мин. наук. Новосибирск, 2000, 19 с.

Каныгин А.В., Ядренкина А.Г., Тимохин А.В., Москаленко Т.А., Сычев О.В. Стратиграфия нефтегазоносных бассейнов Сибири. Ордовик Сибирской платформы. Новосибирск: «ГЕО», 2008, 269 с.

Каширцев В.А., Парфенова Т.М., Моисеев С.А., Черных А.В., Новиков Д.А., Бурштейн Л.М., Долженко К.В., Рогов В.И., Мельник Д.С., Зуева И.Н., Чалая О.Н. Прямые признаки нефтегазоносности и нефтематеринские отложения Суханского осадочного бассейна Сибирской платформы // Геология и геофизика. 2019, Т. 60, № 10, c. $1472-1487$.

Конторович А.Э., Беляев С.Ю., Конторович А.А., Старосельцев В.С., Мандельбаум М.М., Мигурский А.В., Моисеев С.А., Сафронов А.Ф., Ситников В.С., Филипцов Ю.А., Хоменко А.В., Еремин Ю.Г., Быкова О.В. Тектоническая карта венднижнепалеозойского структурного яруса Лено-Тунгусской провинции Сибирской платформы // Геология и геофизика. 2009, № 8, т.50, с. 851-862. 
Конторович А.Э., Мельников Н.В., Старосельцев В.С, Хоменко А.В. Влияние интрузивных траппов на нефтегазоносность палеозойских отложений Сибирской платформы // Геология и геофизика. 1987, № 5, с. 14-20.

Конторович А.Э., Павлов А.В., Третьяков Г.А., Хоменко А.В. Критерии прогноза нефтегазоносности и рудоносности карбонатно-эвапоритовых бассейнов с интенсивным проявлением траппового магматизма // Доклады РАН. 1997, Т. 353, № 6, с. 801-804. (a)

Конторович А.Э., Павлов А.Л., Хоменко А.В., Третьяков Г.А. Физико-химические условия графитизации углеводородсодержащих пород // Геохимия. 1997, № 6, с. 563571. (б)

Конторович А.Э., Павлов А.Л., Третьяков Г.А., Хоменко А.В. Физико-химическое моделирование равновесий в системе «карбонат-эвапоритовые породы - вода углеводороды» при контактовом метаморфизме и катагенезе // Геохимия. 1996, № 6, с. 611 - 629. (a)

Конторович А.Э., Павлов А.Л., Третьяков Г.А., Хоменко А.В. Физико-химическое моделирование термодинамических равновесий в системе «карбонат-эвапоритовые осадочные породы - вода - углеводороды» при контактовом метаморфизме и катагенезе // Геохимия. 1996, № 7, с. 598-610. (б)

Конторович А.Э., Филипцов Ю.А., Битнер А.К., Стасова О.Ф., Хоменко А.В. Кембрийские газы, нефти и конденсаты на Сибирской платформе в районах интенсивного развития траппового магматизма // Геохимия. 1996, № 9, с. 875-883. (в)

Конторович А.Э., Хоменко А.В. Теоретические основы прогноза нефтегазоносности осадочных бассейнов с интенсивным проявлением траппового магматизма // Геология и геофизика. 2001, Т.42, № 11-12, с.1764-1773. 
Конторович А.Э., Хоменко А.В., Павлов А.Л., Жидкова Л.В., Кузнецова Е.Н.,

Гордеева А.О. Нефтегазовые системы в условиях аномально высоких температур // Проблемы геологии континентов и океанов. Доклады Российских ученых-участников 31-го МГК. Магадан: Кортис, 2001, с. 237-246.

Мазуров М.П., Васильев Ю.Р., Шихова А.В., Титов А.Т. Ассоциации и строение рудных минералов в интрузивных траппах западной части Сибирской платформы //Геология и геофизика. 2014, Т. 55, №1, с. 94-107.

Мазуров М.П., Гришина С.Н., Титов А.Т., Шихова А.В. Эволюция руднометасоматических процессов в крупных скарновых железорудных месторождениях Трапповой формации Сибирской платформы // Петрология. 2018, Т. 26, №3, с. 265-281.

Мазуров М.П., Титов А.Т. Магнезиальные скарны из участков послойных инъекций базитовой магмы в эвапориты платформенного чехла // Геология и геофизика. 1999, Т. 40, № 1, c. 82-89.

Медведев А.Я., Альмухамедов А.И., Рейчов М.К., Сандерс А.Д., Вайт Р.В., Кирда Н.П. Абсолютный возраст базальтов доюрского основания Западно-Сибирской плиты (по ${ }^{40} \mathrm{Ar} /{ }^{39} \mathrm{Ar}$ данным) // Геология и геофизика. 2003, Т. 44, №6, с. 617-620.

Мельников Н.В., Якшин М.С., Шишкин Б.Б., Ефимов А.О., Карлова Г.А., Килина Л.И., Константинова Л.Н., Кочнев Б.Б., Краевский Б.Г., Мельников П.Н., Наговицин К.Е., Постников А.А., Рябкова Л.В., Терлеев А.А., Хабаров Е.М. Стратиграфия нефтегазоносных бассейнов Сибири. Рифей и венд Сибирской платформы и ее складчатого обрамления. Новосибирск: «ГЕО», 2005, 428 с.

Новиков Д.А., Кох А.А. Геотермическая модель юго-западной части Курейской синеклизы в связи с нефтегазоносностью // Геология нефти и газа. 2014, №1, с. 112-119. 
Полянский О.П., Ревердатто В.В. Конвекция флюида в коллекторах осадочного бассейна при термическом воздействии даек и силлов // Геология и геофизика. 2002, №. 1, c. 27-41.

Полянский О.П., Ревердатто В.В. Роль флюида в тепломассопереносе при эволюции осадочных бассейнов с трапповым магматизмом // Флюиды и геодинамика: материалы Всерос. симпозиума “Глубинные флюиды и геодинамика“. Москва: Наука, 2006, 219243 c.

Сидкина Е.С. Геохимия подземных рассолов Тунгусского и Оленекского артезианских бассейнов (Сибирская платформа) // Литология и полезные ископаемые. 2018, Т. 53, №1, c. 252-262.

Соболев В.С. Петрология траппов Сибирской платформы. Труды Всесоюзного Арктического института. Т. 43. Ленинград: Изд-во ГУ Севморпути, 1936, 224 с.

Сухов С.С., Шабанов Ю.Я., Пегель Т.В., Сараев С.В., Филиппов Ю.Ф., Коровников И.В., Сундуков В.М., Федоров А.Б., Варламов А.И., Ефимов А.С., Конторович В.А., Конторович А.Э. Стратиграфия нефтегазоносных бассейнов Сибири. Кембрий Сибирской платформы. Том 1. Новосибирск: «ГЕО», 2016, 497 с.

Тесаков Ю.И., Предтеченский Н.Н., Лопушинская Т.В., Хромых В.Г., Базарова Л.С., Бергер А.Я., Ковалевская Е.О. Стратиграфия нефтегазоносных бассейнов Сибири. Силур Сибирской платформы. Новосибирск: «ГЕО», 2000, 403 с.

Хоменко А.В. Влияние траппового магматизма на нефтегазоносность Тунгусского осадочного бассейна: автореферат дисс. ... доктора геол.-мин. Наук. Новосибирск, 1997, 35 c.

Шарапов В.Н., Борисенко А.С., Мазуров М.П., Лебедев В.И., Павлова Г.А., Сотников В.И., Гаськов И.В., Пономарчук В.А., Житова Л.М., Перепечко Ю.В., Попов В.Н., Черепанова В.К., Черепанов А.Н. Модельный анализ развития 
континентальных мантийно-коровых рудообразующих систем. Новосибирск: Изд-во PAH, 2009, 408 c.

Шварцев С.Л. Химический состав и изотопы стронция рассолов Тунгусского бассейна в связи с проблемой их формирования // Геохимия. 2000, №11, с. 1170-1184.

Grishina S., Dubessy J., Kontorovich A., Pironon J. Inclusions in salt beds resulting from thermal metamorphism by dolerite sills (Eastern Siberia, USSR) // European Journal of Mineralogy. 1992, v. 4, pp. 117-120.

Iacono-Marziano G., Morizet Y., Le Trong E., Gaillard F. New experimental data and semi-empirical parameterization of $\mathrm{H}_{2} \mathrm{O}-\mathrm{CO}_{2}$ solubility in mafic melts // Geochimica et Cosmochimica Acta. 2012, v. 97, pp. 1-23.

Novikov D.A. Hydrogeochemistry of the Arctic areas of Siberian petroleum basins // Petroleum Exploration and Development. 2017, v. 44, №5, pp. 780-788. (a)

Novikov D.A. Distribution of cambrian salts in the Western Siberian craton (YurubchenoTokhomo field, Russia) // Arabian Journal of Geosciences. 2017, v. 10, №1, 7p. (б)

Novikov D.A. Genetic classification of subsurface waters and brines of Arctic regions of Siberia // IOP Conference Series: Earth and Environmental Science. 2018, v. 193, №012049.

Novikov D.A., Chernykh A.V., Dultsev F.F. Geochemistry of brines in Vendian deposits of the Siberian platform // IOP Conference Series: Earth and Environmental Science. 2018, v. 193, №012052.

Novikov D.A., Zhitova L.M., Dultsev F.F., Chernykh A.V. Primary data on the impact from trap magmatism on the hydrogeochemistry of brines in the southwestern part of the Kureyka syncline (Siberian Platform) // E3S Web of Conferences. 2019, v. 98, № 08017.

Novikov D.A., Trifonov N.S. Hydrogeologic implications of industrial effluent disposal of the Yurubcheno-Tokhomo field (Siberian craton, Russia) // Arabian Journal of Geosciences. 2016, v. 9, №1, pp. 1-14. 
Polansky O.P., Reverdatto V.V., Khomenko A.V., Kuznetsova E.N. Modeling of fluid flow and heat transfer induced by basaltic near-surface magmatism in the Lena-Tunguska petroleum basin (Earster Siberia, Russia) // Journal of geochemical exploration. 2003, v. 7879, pp. 687-692.

Ryabov V.V., Lapkovsky A.A. Native iron (-platinum) ores from the Siberian Platform trap intrusions // Australian Journal of Earth Sciences. 2010, v. 57, pp. 1-30.

Svensen H., Planke S., Polozov A.G., Schmidbauer N., Corfu F., Podladchikov Y.Y., Jamtveit B. Siberian gas venting and the end-Permian environmental crisis // Earth and Planetary Science Letters. 2009, v. 277, pp. 490-500. 
Рис. 1. Местоположение района исследований с элементами тектонического районирования венд-силурийского структурного яруса Лено-Тунгусской НГП Сибирской платформы (по [Конторович и др., 2009]).

границы: 1 - дизъюнктивных нарушений; тектонических элементов: 2 - первого порядка и надпорядковых структур; 3 - отрицательных второго порядка (1 - Биромбинская котловина, 2 - Кочумдэкская котловина, 3 - Фатьяниховский структурный залив, 4 Караульская котловина, 5 - Тембенчинский прогиб); 4 - положительных второго порядка( 6 - Сенгачангдский структурный мыс, 7 - Кондроминское куполовидное поднятие, 8 - Верхнеамнуннаканское куполовидное поднятие); 5 - линия геологического разреза I-I (рис. 3); 6 - глубокие скважины.

Рис. 2. Сводный литолого-стратиграфический разрез осадочных образований ЮжноТунгусской НГО

1 - известняки, 2 - доломиты, 3 - известняки глинистые, 4 - доломиты глинистые, 5 глины, 6 - аргиллиты, 7 - алевролиты, 8 - песчаники, 9 - мергели, 10 - угли, 11 ангидриты-сульфаты, 12 - кавернозность, 13 - органогенность, 14 - битуминозность, 15 соли, 16 - пиритизированность, 17 - туфы, брекчированные туфы, 18 - перерывы в осадконакоплении, 19 - стратиграфическое несогласие.

Рис. 3. Современное положение трапповых тел в разрезе осадочного чехла по линии скважин Моктаконская-7 - Усть-Кочумдекская-202

1 - траппы; 2 - скважины; 3 - границы стратиграфических подразделений.

Стратиграфические подразделения: T - триас; $\mathrm{C}_{2}-\mathrm{P}$ - карбон-пермь; D - девон; $\mathrm{S}_{2}$ - верхний силур; $\mathrm{S}_{1}$ - нижний силур; $\mathrm{O}_{2}$-средний ордовик; $\epsilon_{3}$ - верхний кембрий; $\epsilon_{2}$ - средний кембрий; $\epsilon_{1}$ - нижний кембрий; V - венд. Свиты: dj - дьявольская; vl+mg - валекская и могоктинская; nr - неручандская; bk - байкитская, um - усть-мундуйская, up - устьпелядкинская, lt - летнинская, ol - оленчиминская, ск - соленосно-карбонатная, и известняковая, ги - глинистых известняков, tn+dl - таначинская+дельтулинская, sr сурингдаконская, br - бурусская, ab - абакунская, mr - марская, mkt - моктаконская, js ясенгская, $\mathrm{tt}+\mathrm{sb}$ - тэтэрская+собинская, kt - катангская. Аббревиатура скважин: КЧ Кочумдекская, МК - Моктаконская, ПМ - Пойменная, УКч - Устькочумдекская.

Рис 4. Модель распределения современных пластовых температур в кровле основных стратиграфических уровней кембрия западной части Курейской синеклизы 
1 - скважина и ее номер; 2 - дизъюнктивные нарушения; 3 - границы тектонических элементов; 4 - кровли стратиграфических подразделений: 1 - устьмундуйской свиты $\left(\epsilon_{2-3}\right)$; 2 -дельтулинской свиты $\left(\epsilon_{1} \mathrm{dl}\right) ; 3$ - булайской свиты $\left(\epsilon_{1} \mathrm{bl}\right) ; 4$ - бурусской свиты $\left(\epsilon_{1} \mathrm{br}\right) ; 5$ усольской свиты ( $\left.\epsilon_{1} \mathrm{us}\right) ; 6$ - тэтэрской свиты $\left(\mathrm{V}-\mathrm{G}_{1}\right) ; 7$ - кристаллического фундамента. Аббревиатура скважин: Ан - Анакитская, Бур - Бурусская, Бх - Бахтинская, ВНг Восточно-Ногинская, ЗМл - Западно-Малькитконская, ЗНг - Западно-Ногинская, Кчм Кочумдекская, Мк - Моктаконская, Мрс - Марская, Нт - Нижнетунгусская, Св - Светлая, Тнч - Таначинская, Уд - Устьдельтулинская, Хр - Хурингдинская.

Рис. 5. Карты распределения расчетных температур в продуктивных горизонтах после внедрения интрузий траппов: а - дьявольский (силур), б - байкитский (средний ордовик), в - дельтулино-таначинский (нижне-средний кембрий), г - абакунский (нижний кембрий), д - моктаконский (нижний кембрий)

1 - изотермы, 2 - скважины, которые вскрыли продуктивный горизонт. Аббревиатура скважин: Ан - Анакитская, Бр - Бурусская, Бх - Бахтинская, Вам Верхнеамнуннаканская, Вк - Вакунайская, ВНг - Восточно-Ногинская, ЗМл - ЗападноМалькитконская, ЗНг - Западно-Ногинская, Кч - Кочумдекская, Мк - Моктаконская, Мл Малькитконская, Мр - Марская, Нм - Намурская, Нт - Нижнетунгусская, Пм Пойменная, Ср - Сурингдаконская, Тн - Таначинская, Тт - Тутончанская, Удл Устьдельтулинская, Укч - Устькочумдекская, Уч - Учаминская, Хл - Холминская, Чс Чисковская.

Рис. 6. Диаграмма Пайпера состава рассолов западных районов Курейской синеклизы

Рис. 7. Диаграммы общего состава газов и состава тяжелой углеводородной фракции водорастворенных газов (а-б) и свободных газов залежей (в-г) западных районов Курейской синеклизы

Рис. 8. Степень метаморфизации (S) рассолов западных районов Курейской синеклизы

Градации рассолов по степени метаморфизации $(\mathrm{S}): \mathrm{S}_{1}-$ слабой, $\mathrm{S}_{2}-$ средней и $\mathrm{S}_{3}-$ сильной. Стрелкой показано направление метаморфизации. 
Рис. 9. Зависимость $\mathrm{rNa} / \mathrm{rCl}, \mathrm{Cl} / \mathrm{Br}, \mathrm{Ca} / \mathrm{Cl}, \mathrm{Sr} /\left(\mathrm{Cl}^{*} 10^{-3}\right), \mathrm{Br} /\left(\mathrm{Cl}^{*} 10^{-3}\right)$ и $\mathrm{S}$ коэффициентов от величины общей минерализации рассолов западных районов Курейской синеклизы

Рис. 10. Содержание $\mathrm{I}, \mathrm{SiO}_{2}, \mathrm{Al}(\mathrm{a})$ и $\mathrm{B}, \mathrm{NH}_{4}{ }^{+}, \mathrm{Fe}_{\text {общ }}$ (б) в рассолах в зависимости от расстояния до ближайшей интрузии

Рис. 11. Содержание $\mathrm{CH}_{4}$ и $\mathrm{CO}_{2}$ (а) и гомологов метана (б) в составе свободных и водорастворенных газов в зависимости от расстояния до ближайшей интрузии 
Таблица 1.

Типовые пробы рассолов западных районов Курейской синеклизы

\begin{tabular}{|c|c|c|c|c|c|c|c|c|c|c|c|c|c|c|c|c|c|}
\hline \multirow{2}{*}{$\begin{array}{c}\text { Площадь, № } \\
\text { скв }\end{array}$} & \multirow{2}{*}{$\begin{array}{c}\text { Инте } \\
\text { рвал, } \\
\text { м }\end{array}$} & \multirow{2}{*}{$\begin{array}{l}\text { Bo } \\
\text { зра } \\
\text { ст }\end{array}$} & \multirow{2}{*}{$\mathrm{pH}$} & \multicolumn{8}{|c|}{ Показатели, г/дм³ } & \multirow{2}{*}{$\frac{\mathrm{мг} / \text { дм }^{3}}{\mathrm{I}}$} & \multicolumn{3}{|c|}{ Коэффициенты } & \multirow{2}{*}{$\begin{array}{c}\mathrm{M}, \\
\Gamma / \mathrm{AM}^{3}\end{array}$} & \multirow{2}{*}{$\begin{array}{c}\text { Хим. } \\
\text { тип }\end{array}$} \\
\hline & & & & $\mathrm{Cl}^{-}$ & $\mathrm{HCO}_{3}{ }^{2-}$ & $\mathrm{SO}_{4}{ }^{2-}$ & $\begin{array}{l}\mathrm{Na}^{+} \\
+\mathrm{K}^{+}\end{array}$ & $\mathrm{Ca}^{2+}$ & $\mathrm{Mg}^{2+}$ & $\mathrm{Br}^{-}$ & $\mathrm{Sr}^{2+}$ & & $\begin{array}{c}\mathrm{rNa} / \\
\mathrm{rCl}\end{array}$ & $\mathrm{Cl} / \mathrm{Br}$ & S & & \\
\hline \multicolumn{18}{|c|}{ Надсолевая формация } \\
\hline $\begin{array}{c}\text { Нижне- } \\
\text { Тунгусская, } 2\end{array}$ & $\begin{array}{l}1773- \\
1848\end{array}$ & $\epsilon_{2}$ & 6,0 & 125 & 0,2 & 0,6 & 39,1 & 28,8 & 6,9 & 2,7 & - & 6,1 & 0,39 & 45 & 175 & 203,7 & $\begin{array}{c}\mathrm{Cl} \mathrm{Ca}- \\
\mathrm{Na}\end{array}$ \\
\hline Таначинская, 2 & $\begin{array}{l}1778- \\
1889\end{array}$ & $\epsilon_{2}$ & 5,6 & 166 & 0,5 & 0,2 & 65,0 & 35,3 & 1,5 & 0,3 & - & 4,0 & 0,60 & 504 & 162 & 269,3 & $\begin{array}{c}\mathrm{Cl} \mathrm{Na}- \\
\mathrm{Ca}\end{array}$ \\
\hline $\begin{array}{c}\text { Ирбуклинская, } \\
1 \\
\end{array}$ & $\begin{array}{l}2334- \\
2439 \\
\end{array}$ & $\mathrm{O}_{2}$ & - & 166 & 0,1 & 0,2 & 40,5 & 53,0 & 5,1 & 3,5 & 3,4 & 8,9 & 0,32 & 47 & 243 & 268,4 & $\begin{array}{c}\mathrm{Cl} \mathrm{Ca}- \\
\mathrm{Na}\end{array}$ \\
\hline Анакитская, 1 & $\begin{array}{l}1450- \\
1470\end{array}$ & $\epsilon_{2}$ & 5,9 & 219 & 0,2 & - & 44,7 & 70,1 & 9,1 & 4,0 & - & 53,0 & 0,31 & 55 & 244 & 364,4 & $\begin{array}{c}\mathrm{Cl} \mathrm{Ca}- \\
\mathrm{Na}\end{array}$ \\
\hline $\begin{array}{c}\text { Верхне- } \\
\text { Нимдинская, } 1\end{array}$ & $\begin{array}{l}2553- \\
2615\end{array}$ & $\epsilon_{2}$ & 5,6 & 204 & 0,5 & 0,2 & 49,6 & 52,4 & 11,7 & 2,6 & 0,6 & 10,2 & 0,37 & 77 & 218 & 321,1 & $\begin{array}{c}\mathrm{Cl} \mathrm{Ca}- \\
\mathrm{Na}\end{array}$ \\
\hline \multicolumn{18}{|c|}{ Соленосная формация } \\
\hline Пойменная, 1 & $\begin{array}{l}2410- \\
2502\end{array}$ & $\epsilon_{1}$ & - & 190 & 0,3 & 0,1 & 40,1 & 65,7 & 8,2 & 3,8 & 2,0 & 1,0 & 0,33 & 49 & 341 & 308,1 & $\begin{array}{c}\mathrm{Cl} \mathrm{Ca}- \\
\mathrm{Na}\end{array}$ \\
\hline $\begin{array}{c}\text { Моктаконская, } \\
6 \\
\end{array}$ & $\begin{array}{l}3119- \\
3192\end{array}$ & $\epsilon_{1}$ & - & 209 & 1,9 & 0,6 & 66,7 & 44,6 & 9,9 & - & 1,5 & - & 0,49 & - & 162 & 333,1 & $\begin{array}{c}\mathrm{Cl} \mathrm{Na}- \\
\mathrm{Ca}\end{array}$ \\
\hline Таначинская ,6 & $\begin{array}{l}1889- \\
1917 \\
\end{array}$ & $\epsilon_{1}$ & 5,2 & 217 & 0,6 & 0,1 & 46,0 & 64,8 & 11,2 & 4,4 & 2,9 & - & 0,32 & 49 & 227 & 344,8 & $\begin{array}{c}\mathrm{Cl} \mathrm{Ca}- \\
\mathrm{Na}\end{array}$ \\
\hline $\begin{array}{c}\text { Кочумдекская, } \\
2 \\
\end{array}$ & $\begin{array}{l}2485- \\
2500 \\
\end{array}$ & $\epsilon_{1}$ & 5,5 & 224 & 0,5 & 0,1 & 57,3 & 71,6 & 7,9 & 4,7 & 2,8 & 0,8 & 0,26 & 47 & 243 & 366,8 & $\begin{array}{c}\mathrm{Cl} \mathrm{Ca-} \\
\mathrm{Na}\end{array}$ \\
\hline Байкитская, 1 & $\begin{array}{l}2725- \\
2813\end{array}$ & $\epsilon_{1}$ & - & 263 & - & 4,7 & 44,9 & 99,9 & 15,1 & 5,8 & 1,7 & 1,3 & 0,12 & 46 & 294 & 436,3 & $\mathrm{Cl} \mathrm{Ca}$ \\
\hline \multicolumn{18}{|c|}{ Подсолевая формация } \\
\hline $\begin{array}{c}\text { Холминская, } \\
212\end{array}$ & $\begin{array}{l}3710- \\
3720\end{array}$ & $\epsilon_{1}$ & 4,6 & 218 & - & 0,2 & 58,7 & 65,1 & 8,5 & 4,5 & 5,6 & - & 0,30 & 49 & 227 & 355,9 & $\begin{array}{l}\mathrm{Cl} \mathrm{Ca-} \\
\mathrm{Na}\end{array}$ \\
\hline
\end{tabular}

Примечание: «-» - нет данных. 
Таблица 2.

Содержания некоторых элементов и соединений в рассолах западных районов Курейской синеклизы

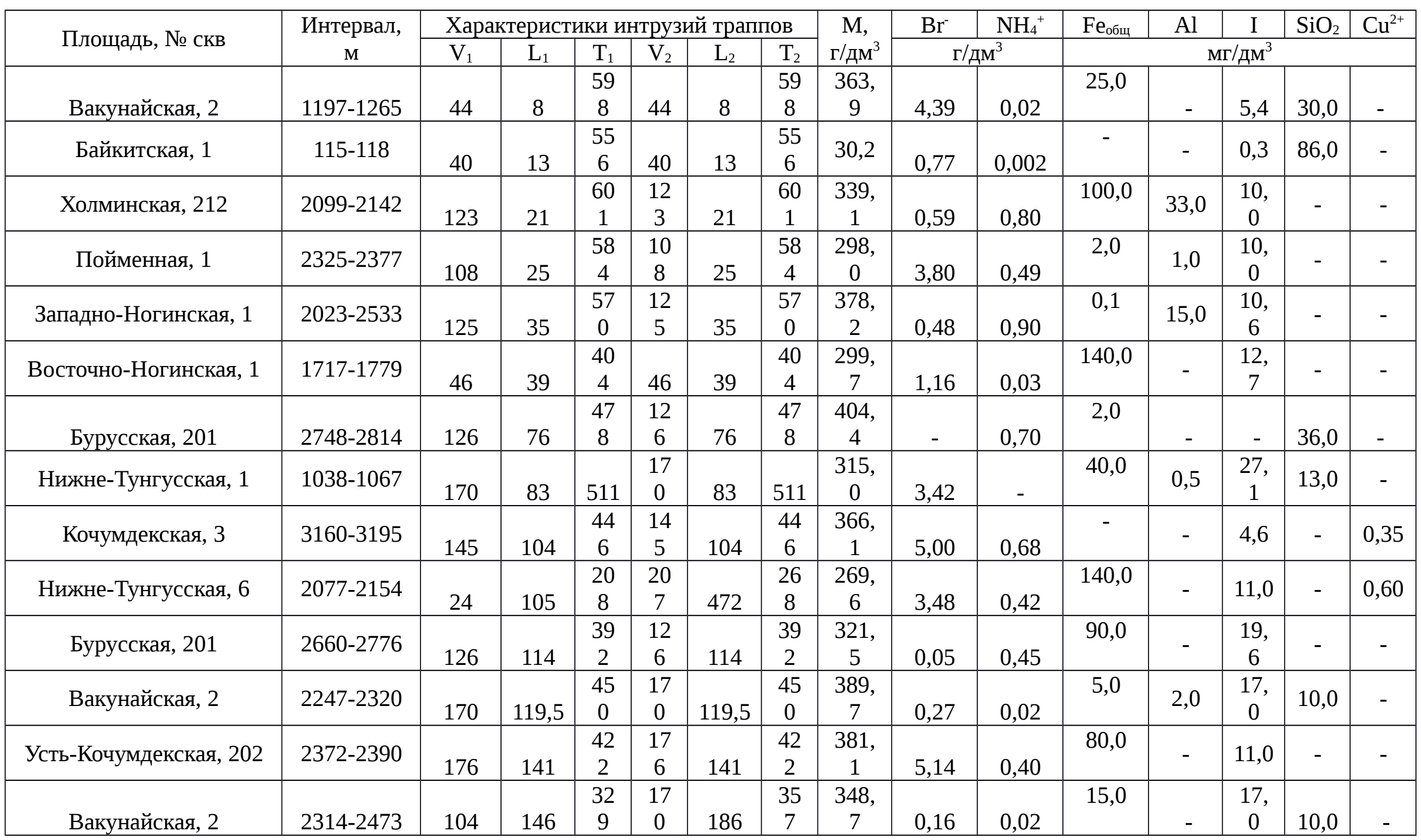




\begin{tabular}{|c|c|c|c|c|c|c|c|c|c|c|c|c|c|c|c|}
\hline Таначинская, 2 & $1883-1930$ & 20 & 156 & $\begin{array}{c}17 \\
3 \\
\end{array}$ & $\begin{array}{c}10 \\
2 \\
\end{array}$ & 282 & $\begin{array}{c}25 \\
6 \\
\end{array}$ & $\begin{array}{c}269 \\
3\end{array}$ & 0,33 & 0,03 & 1,0 & - & 4,0 & 20,0 & - \\
\hline Таначинская, 5 & 1910-1988 & 336 & 200 & $\begin{array}{c}48 \\
0 \\
\end{array}$ & $\begin{array}{c}33 \\
6 \\
\end{array}$ & 200 & $\begin{array}{c}48 \\
0 \\
\end{array}$ & $\begin{array}{c}244, \\
6\end{array}$ & - & 0,02 & 0,5 & - & - & 0,2 & - \\
\hline Таначинская, 1 & $3332-3420$ & 113 & 294 & $\begin{array}{c}26 \\
0\end{array}$ & 113 & 294 & $\begin{array}{c}26 \\
0\end{array}$ & $\begin{array}{c}349 \\
4\end{array}$ & 1,16 & 0,70 & 5,0 & & $\begin{array}{c}18, \\
0\end{array}$ & 20,0 & - \\
\hline Моктаконская, 1 & $3151-3200$ & 74 & 303 & $\begin{array}{c}21 \\
3\end{array}$ & 74 & 303 & $\begin{array}{c}21 \\
3\end{array}$ & $\begin{array}{c}313 \\
3\end{array}$ & $\begin{array}{c}0,000 \\
2\end{array}$ & 0,75 & 250,0 & 1,5 & 4,3 & 2,0 & - \\
\hline Бурусская, 201 & $3375-3460$ & 126 & 359 & $\begin{array}{c}25 \\
4 \\
\end{array}$ & $\begin{array}{c}12 \\
6\end{array}$ & 359 & $\begin{array}{c}25 \\
4\end{array}$ & $\begin{array}{c}377, \\
0\end{array}$ & 3,02 & 1,13 & 310,0 & - & $\begin{array}{c}10, \\
0\end{array}$ & 0,1 & - \\
\hline Ирбуклинская, 1 & $2334-2439$ & 53 & 381 & $\begin{array}{c}17 \\
7 \\
\end{array}$ & $\begin{array}{c}12 \\
0\end{array}$ & 894 & $\begin{array}{c}19 \\
2\end{array}$ & $\begin{array}{c}272 \\
4\end{array}$ & 3,13 & 0,21 & - & - & $\begin{array}{c}12, \\
7\end{array}$ & - & 0,10 \\
\hline Ирбуклинская, 1 & $2240-2250$ & 53 & 570 & $\begin{array}{c}14 \\
9 \\
\end{array}$ & $\begin{array}{c}12 \\
0 \\
\end{array}$ & 1083 & $\begin{array}{c}17 \\
5 \\
\end{array}$ & $\begin{array}{c}330, \\
6\end{array}$ & - & $\begin{array}{c}0,000 \\
4\end{array}$ & 2,5 & - & - & 6,3 & - \\
\hline Нижнетунгусская, 6 & $3585-3700$ & 216 & 571 & $\begin{array}{c}25 \\
9 \\
\end{array}$ & $\begin{array}{c}21 \\
6 \\
\end{array}$ & 571 & $\begin{array}{c}25 \\
9 \\
\end{array}$ & $\begin{array}{c}314, \\
7\end{array}$ & 3,68 & 0,58 & 28,0 & - & $\begin{array}{c}10 \\
4\end{array}$ & 10,0 & - \\
\hline Моктаконская, 3 & $3416-3427$ & 61 & 591 & $\begin{array}{c}15 \\
7 \\
\end{array}$ & 61 & 591 & $\begin{array}{c}15 \\
7\end{array}$ & $\begin{array}{c}217 \\
5\end{array}$ & 0,26 & - & 1,1 & 0,4 & - & 5,1 & - \\
\hline Байкитская, 1 & $2725-2813$ & 147 & 703 & $\begin{array}{c}21 \\
7\end{array}$ & $\begin{array}{c}14 \\
7\end{array}$ & 703 & $\begin{array}{c}21 \\
7\end{array}$ & $\begin{array}{c}469, \\
6\end{array}$ & 6,35 & 1,22 & 24,7 & - & 1,6 & - & 1,30 \\
\hline
\end{tabular}

Примечание: ближайшая интрузия: $\mathrm{V}_{1}$ - мощность, $\mathrm{L}_{1}$ - расстояние, $\mathrm{T}_{1}$ - температура прогрева; интрузия оказавшая максимальное температурное воздействие: $\mathrm{V}_{2}-$ мощность, $\mathrm{L}_{2}$ - расстояние, $\mathrm{T}_{2}$ - температура прогрева; «-» - нет данных. 
Таблица 3.

Состав водорастворенных газов западных районов Курейской синеклизы

\begin{tabular}{|c|c|c|c|c|c|c|c|c|c|c|c|c|c|c|c|c|c|c|c|}
\hline \multirow{2}{*}{$\begin{array}{c}\text { Площадь, № } \\
\text { скв }\end{array}$} & \multirow{2}{*}{$\begin{array}{c}\text { Интервал } \\
\text {, м }\end{array}$} & \multicolumn{6}{|c|}{$\begin{array}{c}\text { Характеристики интрузий } \\
\text { траппов }\end{array}$} & \multirow[t]{2}{*}{$\mathrm{CO}_{2}$} & \multirow[t]{2}{*}{$\mathrm{CH}_{4}$} & \multirow[t]{2}{*}{$\mathrm{C}_{2} \mathrm{H}_{6}$} & \multirow[t]{2}{*}{$\mathrm{C}_{3} \mathrm{H}_{8}$} & \multirow[t]{2}{*}{$\mathrm{iC}_{4} \mathrm{H}_{10}$} & \multirow[t]{2}{*}{$\mathrm{nC}_{4} \mathrm{H}_{10}$} & \multirow[t]{2}{*}{$\mathrm{iC}_{5} \mathrm{H}_{12}$} & \multirow[t]{2}{*}{$\mathrm{nC}_{5} \mathrm{H}_{12}$} & \multirow[t]{2}{*}{$\Sigma \mathrm{C}_{6} \mathrm{H}_{14}$} & \multirow[t]{2}{*}{$\begin{array}{c}\sum \mathrm{TV} \\
\mathrm{B}\end{array}$} & \multirow[t]{2}{*}{$\mathrm{N}_{2}$} & \multirow[t]{2}{*}{$\mathrm{He}$} \\
\hline & & $\mathrm{V}_{1}$ & $\mathrm{~L}_{1}$ & $\mathrm{~T}_{1}$ & $\mathrm{~V}_{2}$ & $\mathrm{~L}_{2}$ & $\mathrm{~T}_{2}$ & & & & & & & & & & & & \\
\hline $\begin{array}{c}\text { Нижне- } \\
\text { Тунгусская, } 1 \\
\end{array}$ & $806-845$ & 14 & 27 & $\begin{array}{c}28 \\
1\end{array}$ & 118 & 51 & 527 & 19,1 & 2,4 & 0,030 & 0,0046 & 0,0002 & - & 0,00030 & - & 0,0001 & 0,04 & 78,5 & - \\
\hline $\begin{array}{c}\text { Западно- } \\
\text { Ногинская, } 1 \\
\end{array}$ & $\begin{array}{l}2023- \\
2533\end{array}$ & 125 & 35 & $\begin{array}{c}57 \\
0\end{array}$ & $\begin{array}{c}12 \\
5\end{array}$ & 35 & 570 & 99,9 & 0,1 & 0,015 & 0,0050 & 0,0008 & 0,0030 & 0,00020 & 0,00030 & - & 0,02 & - & - \\
\hline $\begin{array}{c}\text { Восточно- } \\
\text { Ногинская, } 1 \\
\end{array}$ & $\begin{array}{l}1717- \\
1779\end{array}$ & 46 & 39 & $\begin{array}{c}40 \\
4 \\
\end{array}$ & 46 & 39 & 404 & 94,1 & 5,7 & 0,080 & 0,0500 & 0,0050 & 0,0110 & 0,00400 & 0,00600 & - & 0,16 & - & - \\
\hline Таначинская, 7 & $\begin{array}{l}2889- \\
2968\end{array}$ & 31 & 58 & $\begin{array}{c}28 \\
6\end{array}$ & 95 & $\begin{array}{c}10 \\
9\end{array}$ & 347 & 2,1 & 1,4 & 0,004 & 0,0015 & 0,0005 & 0,0011 & 0,00120 & 0,00090 & 0,0014 & 0,01 & 96,5 & - \\
\hline Таначинская, 2 & $\begin{array}{l}1926- \\
1960\end{array}$ & 20 & $\begin{array}{c}15 \\
5\end{array}$ & $\begin{array}{c}17 \\
3\end{array}$ & $\begin{array}{c}10 \\
2\end{array}$ & $\begin{array}{c}32 \\
5\end{array}$ & 245 & 90,2 & 0,1 & 0,011 & 0,0070 & 0,0019 & 0,0041 & 0,00200 & 0,00200 & 0,0010 & 0,03 & 9,6 & - \\
\hline Таначинская, 4 & $\begin{array}{l}1902- \\
1946\end{array}$ & 97 & $\begin{array}{c}17 \\
8\end{array}$ & $\begin{array}{c}28 \\
9 \\
\end{array}$ & 97 & $\begin{array}{c}17 \\
8 \\
\end{array}$ & 289 & 55,6 & 16,5 & 0,600 & 0,4000 & 0,1000 & 0,2000 & - & 0,10000 & - & 1,40 & 26,5 & 0,36 \\
\hline Таначинская, 5 & $\begin{array}{c}1910- \\
1988 \\
\end{array}$ & 336 & $\begin{array}{c}20 \\
0 \\
\end{array}$ & $\begin{array}{c}48 \\
0 \\
\end{array}$ & $\begin{array}{c}33 \\
6 \\
\end{array}$ & $\begin{array}{c}20 \\
0 \\
\end{array}$ & 480 & 13,9 & 70,9 & 3,200 & 0,7800 & 0,1600 & 0,2600 & 0,10500 & 0,07700 & - & 4,58 & 10,7 & 0,09 \\
\hline Марская, 217 & $\begin{array}{l}3238- \\
3293\end{array}$ & 90 & $\begin{array}{c}28 \\
4 \\
\end{array}$ & $\begin{array}{c}23 \\
6 \\
\end{array}$ & 90 & $\begin{array}{c}28 \\
4 \\
\end{array}$ & 236 & 3,8 & 42,8 & 0,900 & 0,1000 & - & - & 0,00500 & 0,00500 & - & 1,01 & 52,2 & 0,23 \\
\hline Таначинская, 1 & $\begin{array}{l}3332- \\
3420\end{array}$ & 113 & $\begin{array}{c}29 \\
4 \\
\end{array}$ & $\begin{array}{c}26 \\
0\end{array}$ & 113 & $\begin{array}{c}29 \\
4\end{array}$ & 260 & 3,4 & 54,6 & 0,076 & 0,0090 & 0,0270 & 0,0087 & 0,00800 & 0,00040 & - & 0,13 & 41,9 & 0,52 \\
\hline Анакитская, 1 & $1132-1136$ & 132 & $\begin{array}{c}32 \\
2\end{array}$ & $\begin{array}{c}26 \\
4 \\
\end{array}$ & $\begin{array}{c}47 \\
0\end{array}$ & $\begin{array}{c}46 \\
2\end{array}$ & 370 & 6,4 & 78,2 & 6,430 & 2,0500 & 1,1400 & 2,5600 & 1,72000 & 0,78000 & 0,7500 & 15,43 & - & - \\
\hline $\begin{array}{l}\text { Моктаконская, } \\
5 \\
\end{array}$ & $\begin{array}{l}3261- \\
3282\end{array}$ & 7 & $\begin{array}{c}35 \\
2\end{array}$ & 66 & 68 & $\begin{array}{c}42 \\
4 \\
\end{array}$ & 185 & 4,1 & 66,6 & 2,100 & 0,1000 & - & 0,5000 & - & - & - & 2,70 & 26,6 & 0,46 \\
\hline $\begin{array}{c}\text { Нижне- } \\
\text { Тунгусская, } 6\end{array}$ & $\begin{array}{l}3386- \\
3443\end{array}$ & 216 & $\begin{array}{c}37 \\
2 \\
\end{array}$ & $\begin{array}{c}30 \\
0\end{array}$ & $\begin{array}{c}21 \\
6 \\
\end{array}$ & $\begin{array}{c}37 \\
2\end{array}$ & 300 & 0,6 & 42,5 & 0,290 & 0,0004 & - & 0,0001 & 0,00002 & 0,00004 & - & 0,29 & 56,7 & 0,37 \\
\hline
\end{tabular}

Примечание: см. табл. 2. 


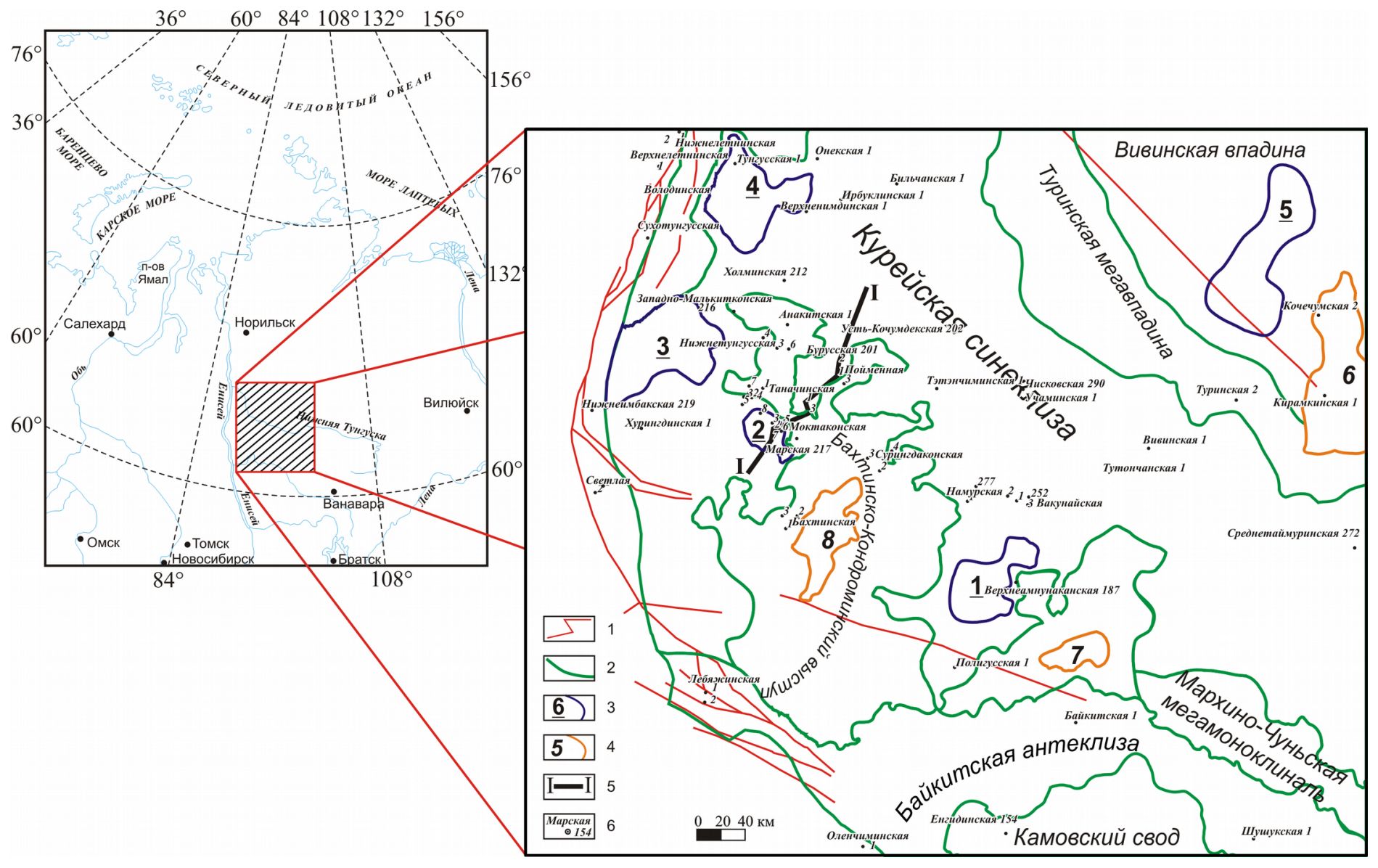



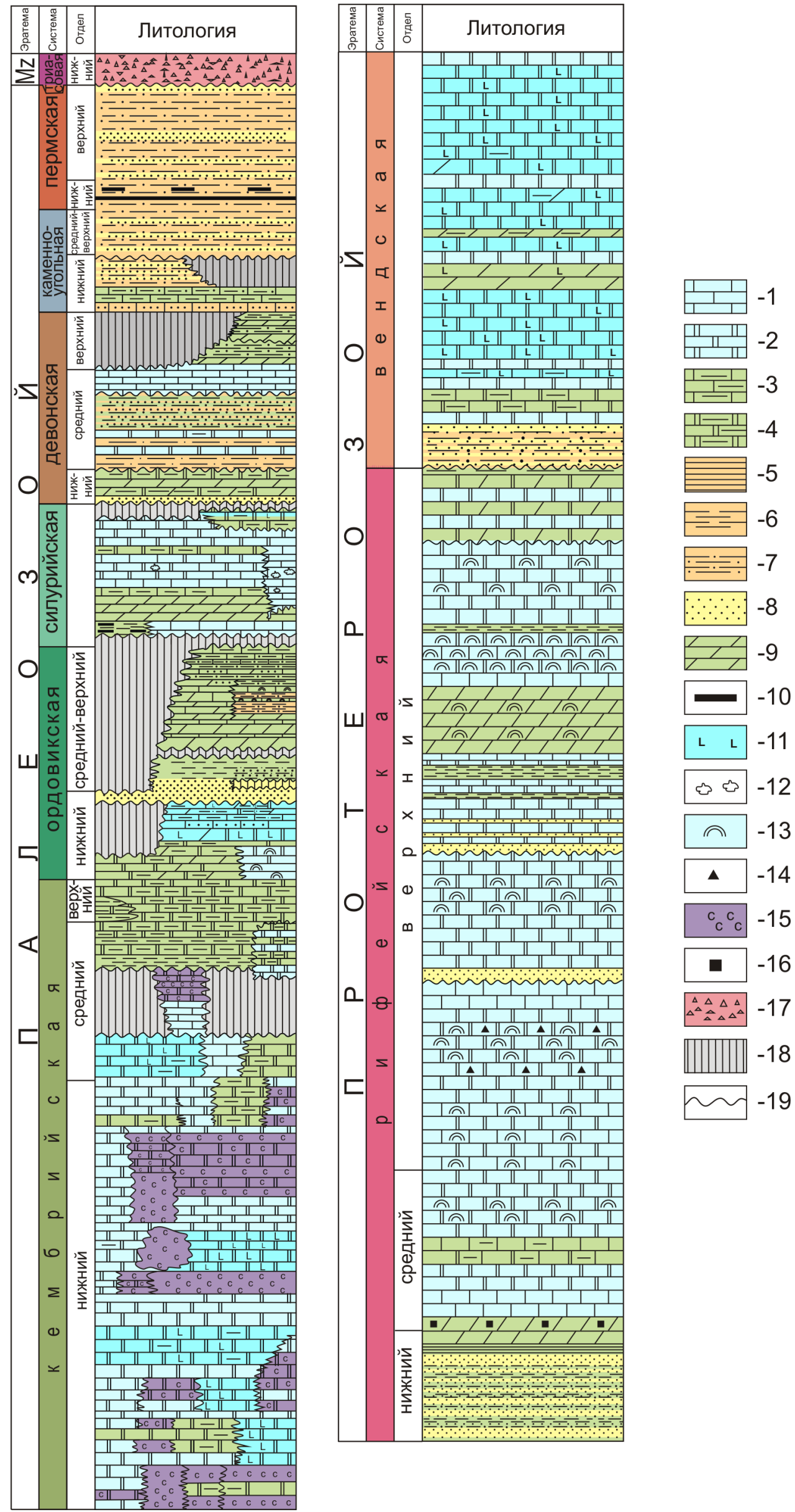


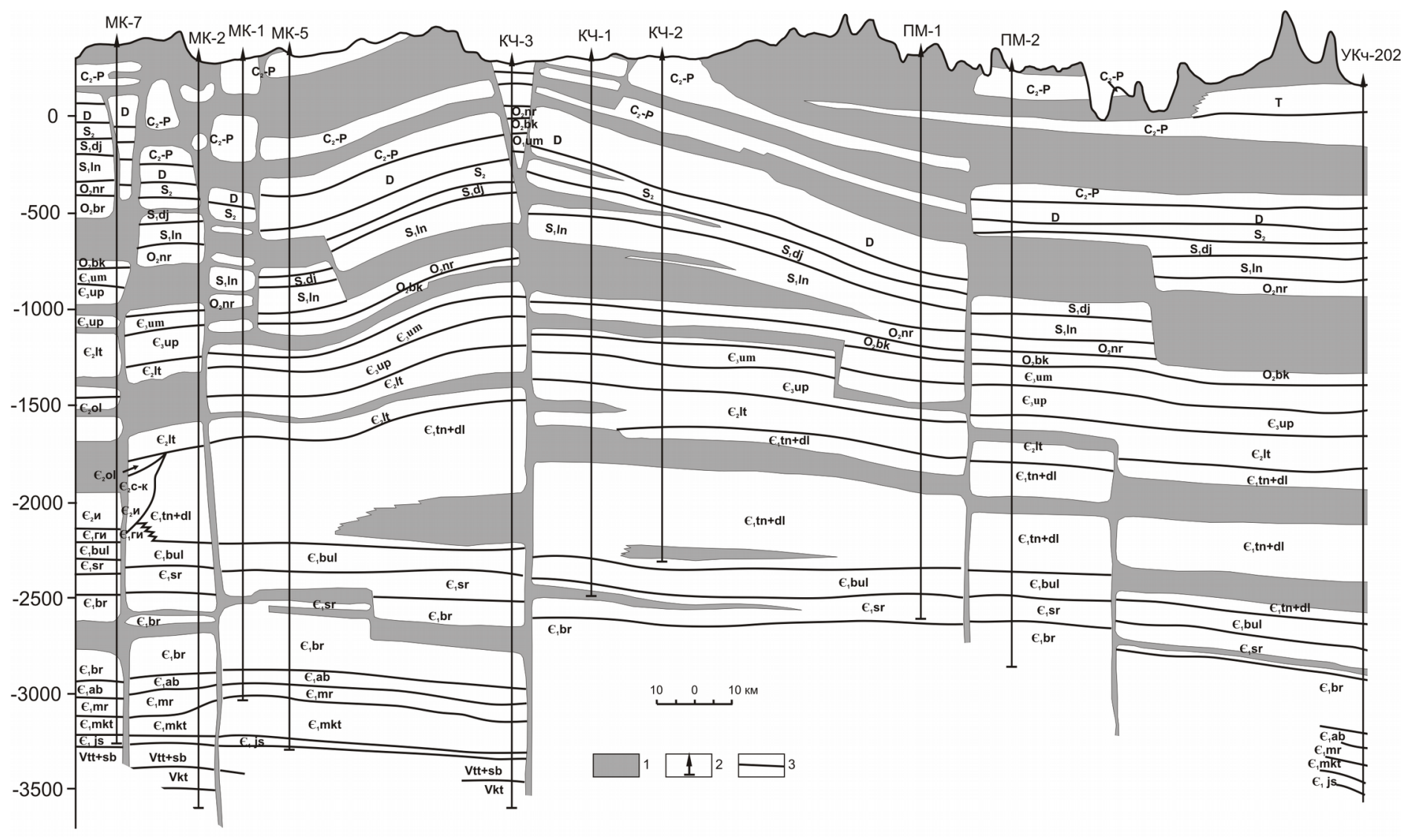




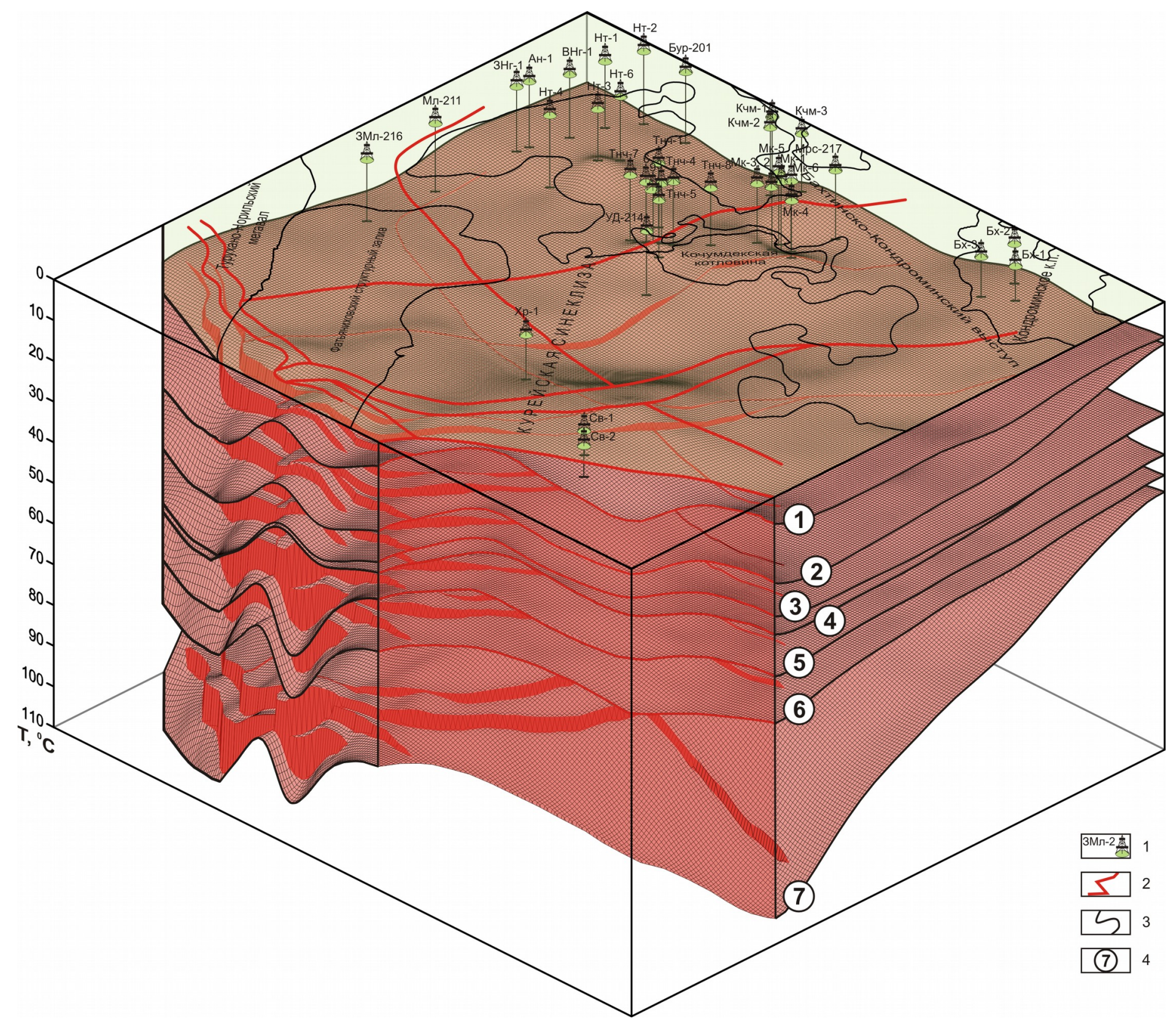



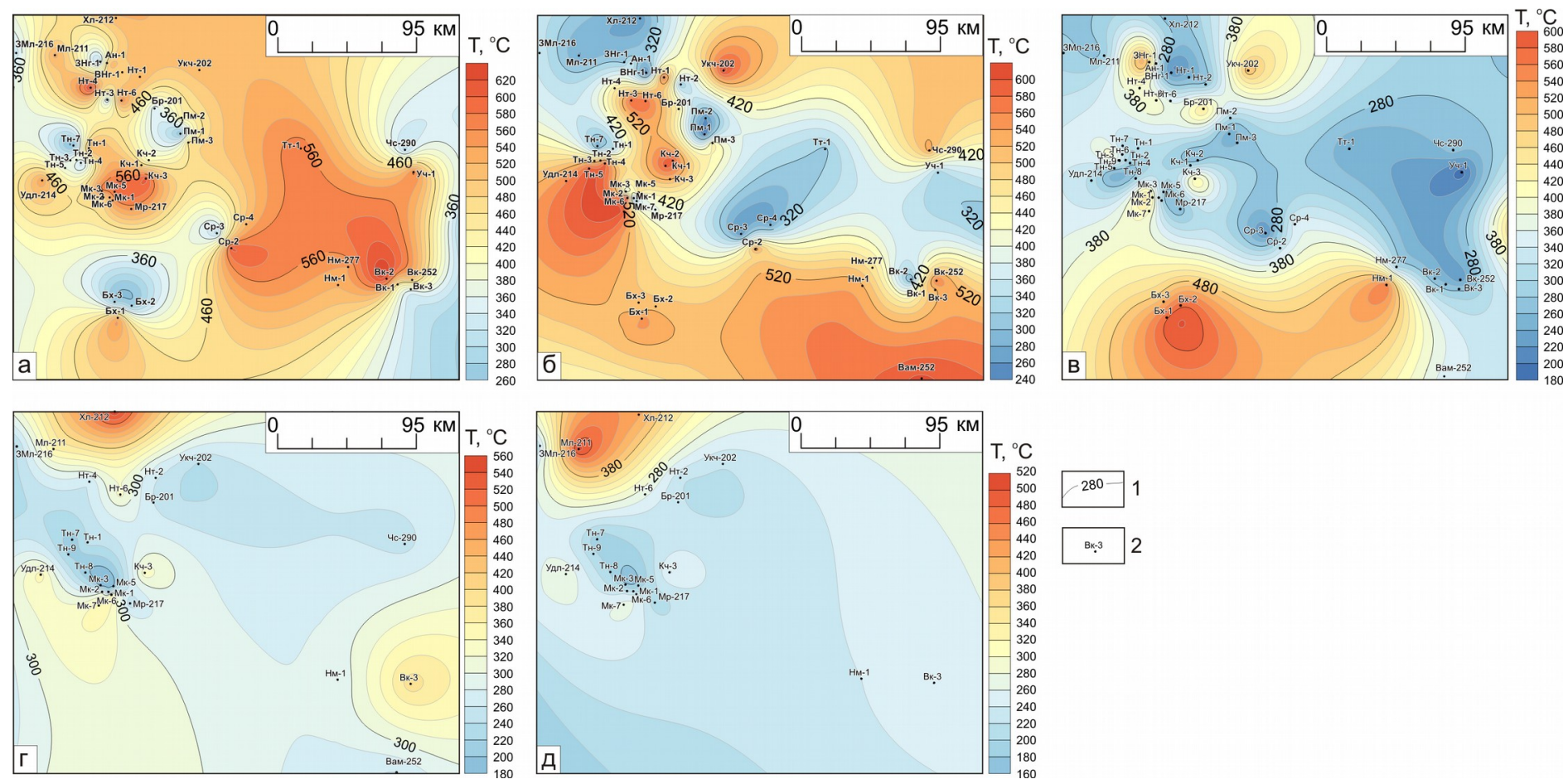


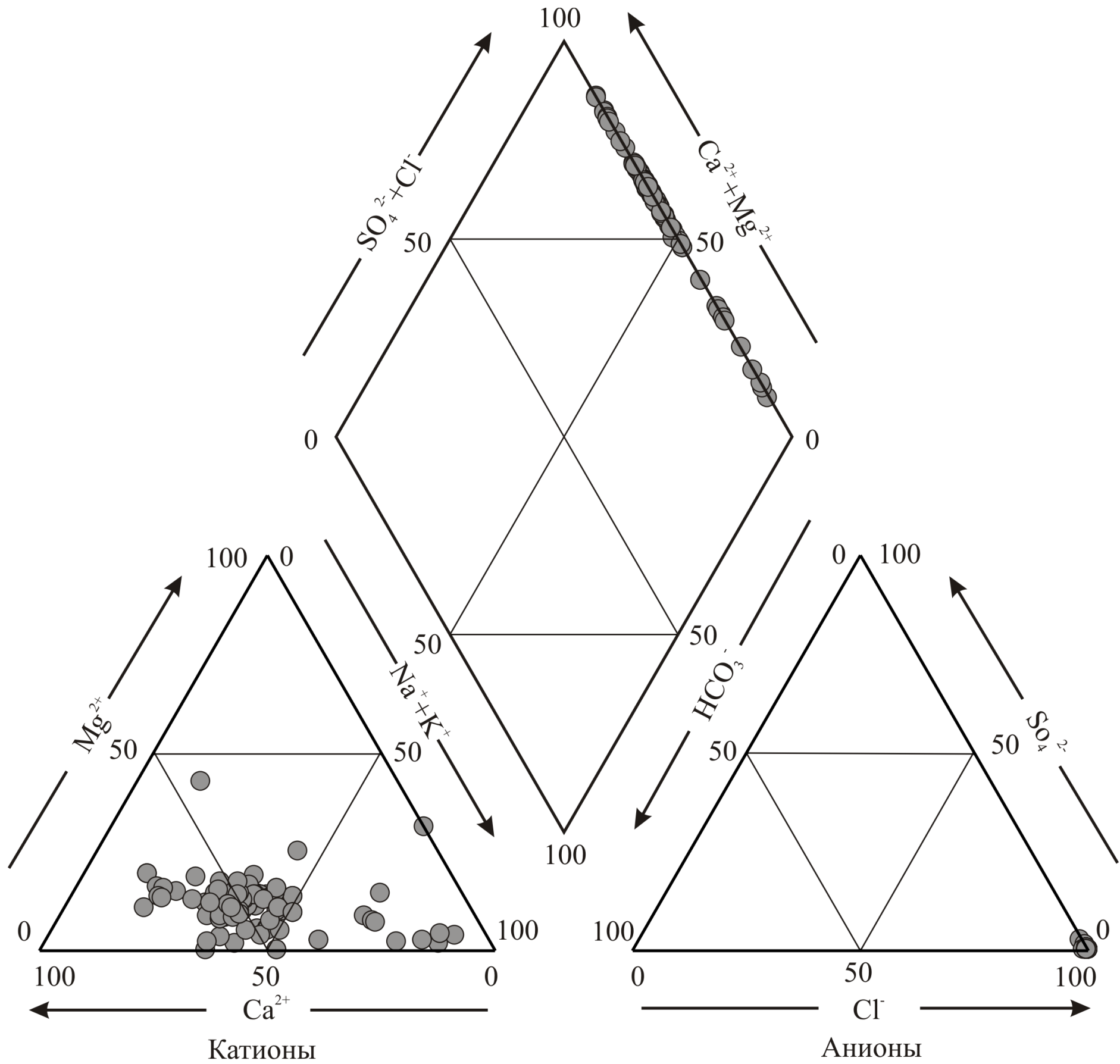



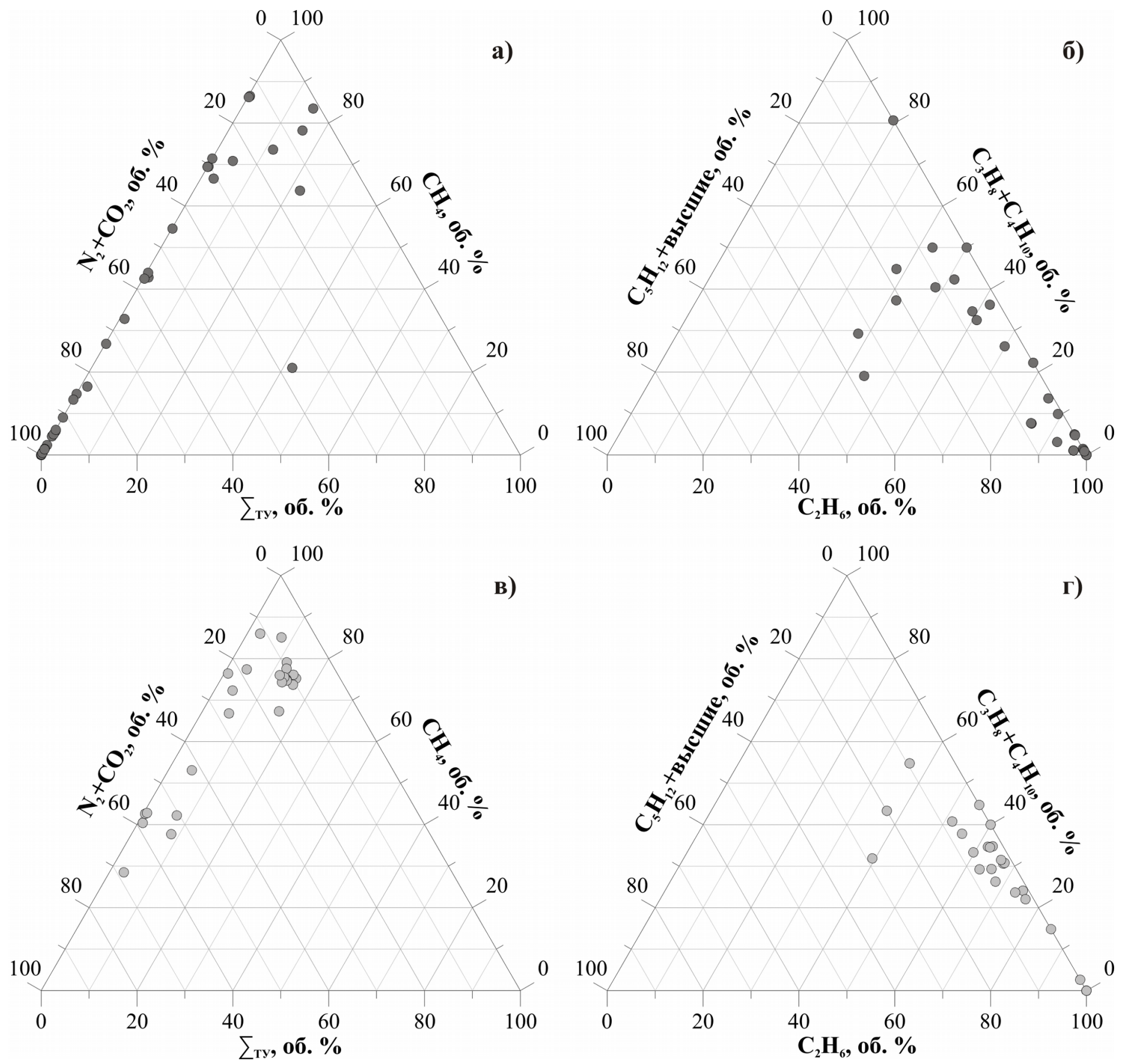


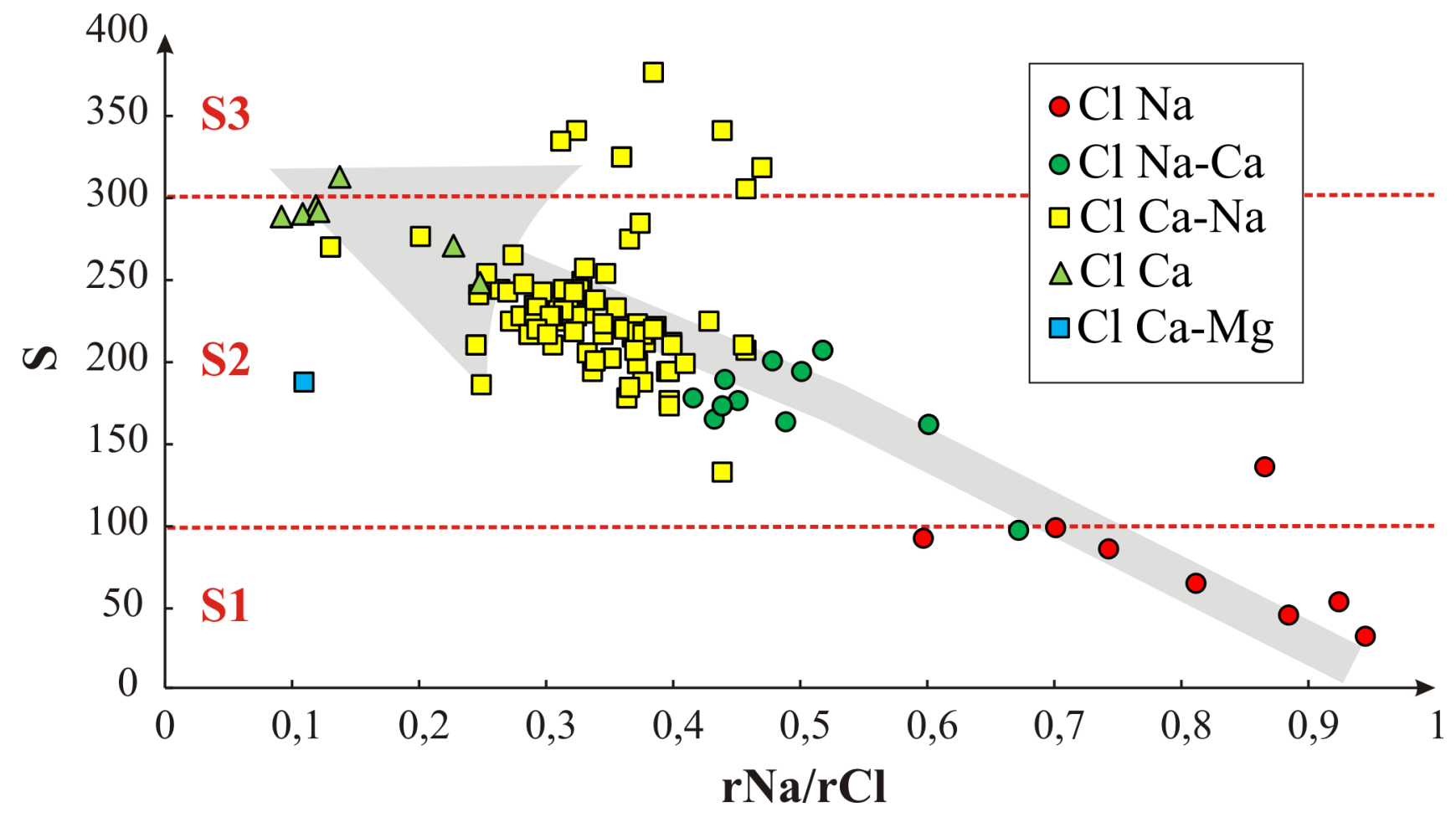



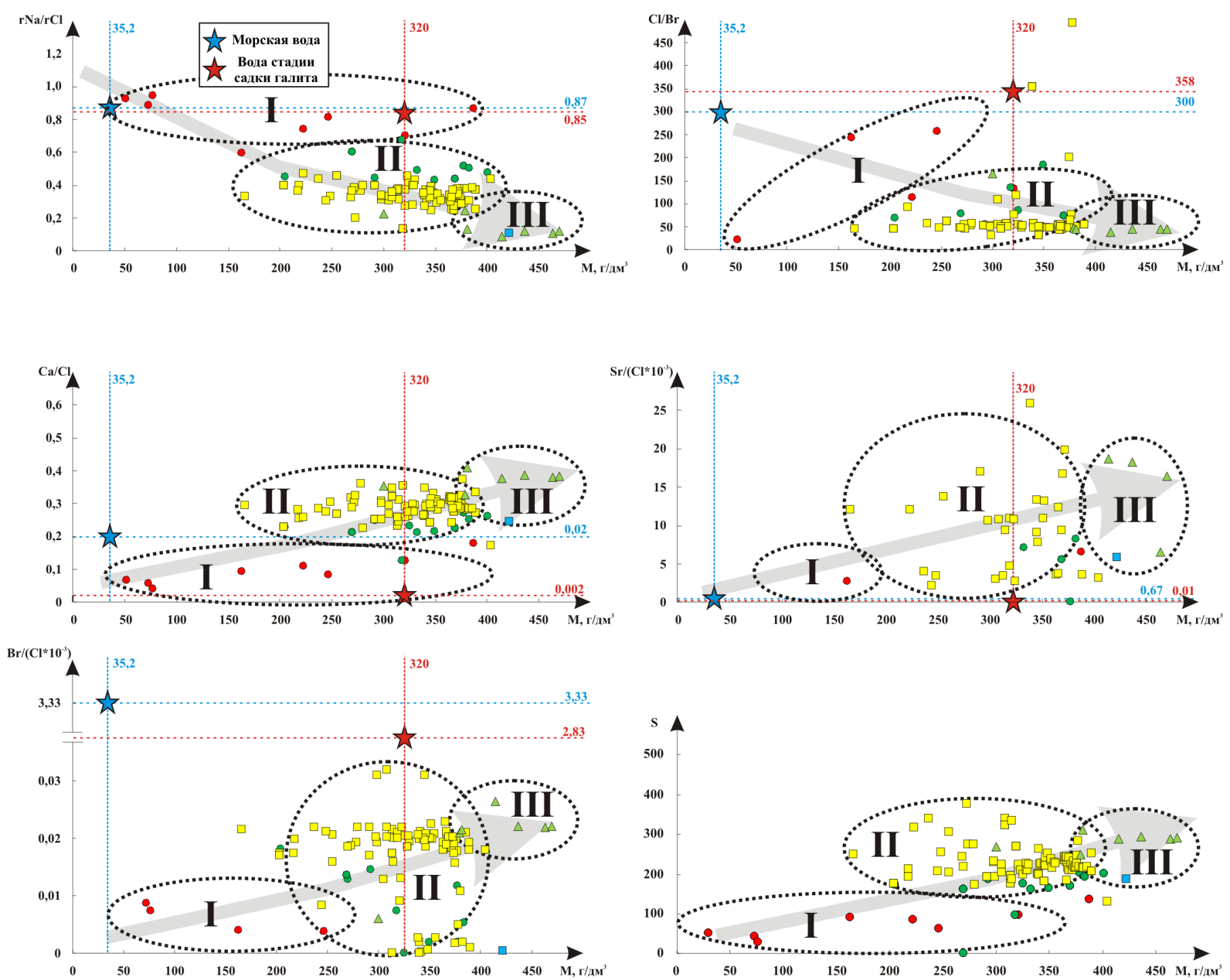

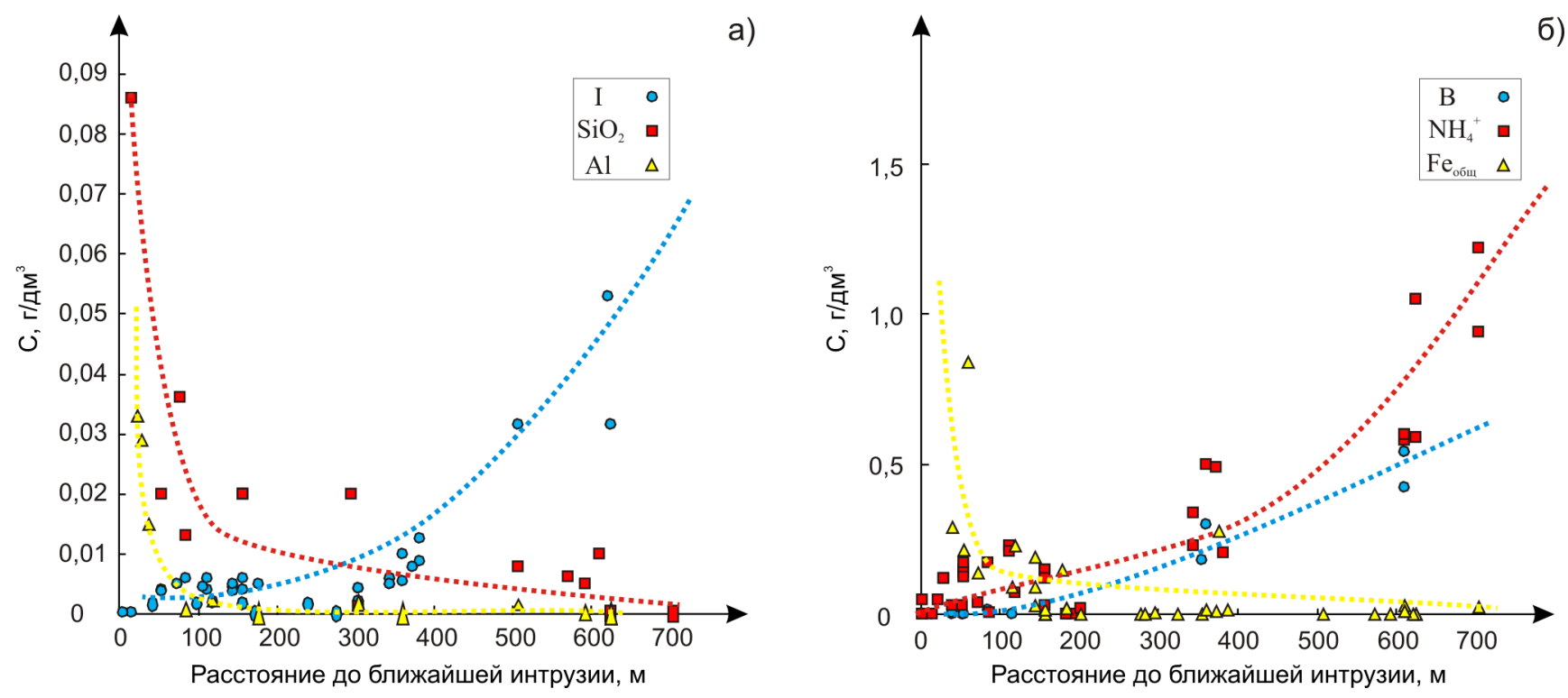
a)

б)
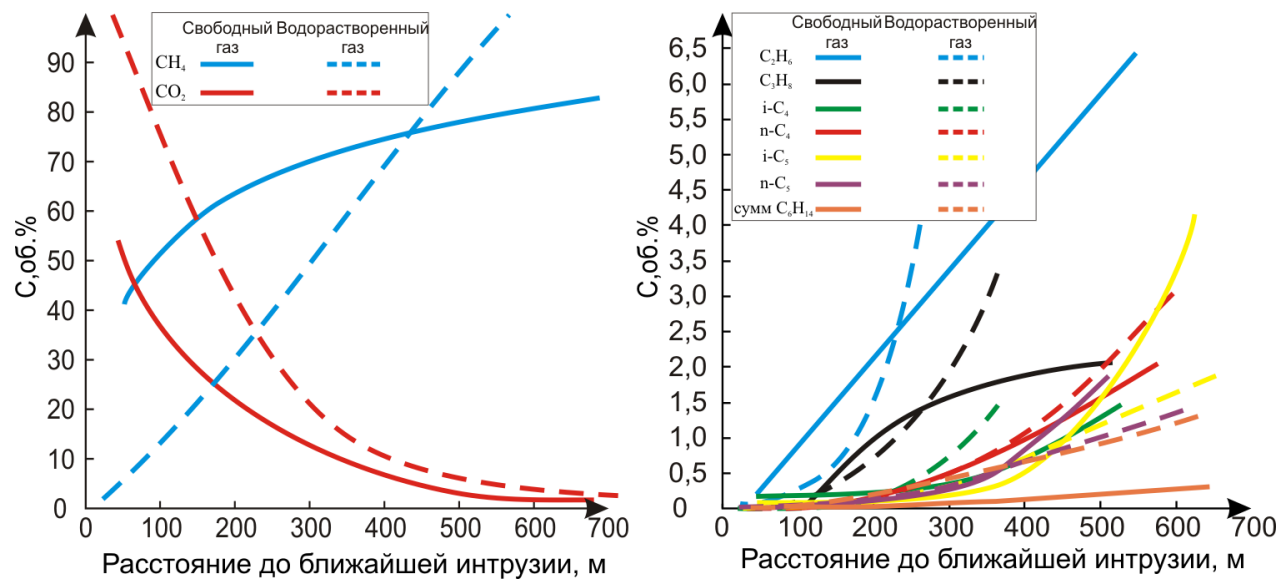